Article

\title{
Expropriation of Real Property in Kigali City: Scoping the Patterns of Spatial Justice
}

\author{
Ernest Uwayezu * and Walter T. de Vries ${ }^{\mathbb{D}}$
}

Lehrstuhl für Bodenordnung und Landentwicklung, Ingenieurfakultät Bau Geo Umwelt, Technische Universität München, Arcisstrasse 21, 80333 München, Germany; wt.de-vries@tum.de

* Correspondence: ernest.uwayezu@tum.de; Tel.: +49-151-4243-7013

Received: 30 December 2018; Accepted: 14 January 2019; Published: 22 January 2019

\begin{abstract}
The key question in this article is the extent to which current real property expropriation practices in Kigali city promote spatial justice. Current studies focus on the ambiguous manner in which real property valuation had been regulated by the expropriation law of 2007, leading to unfair compensation and various conflicts between expropriating agencies and expropriated people. Following its amendment in 2015, the law currently provides clearer procedures for valuation and fair compensation, based on the market prices. Using indicators that measure spatial justice, this study evaluates if the current expropriation processes result in spatial justice, consisting of procedural, recognitional and redistributive justice. These indicators are described using three dimensions of spatial justice: rules, processes and outcomes. Data were collected through household surveys, focus group discussions, stakeholders' interviews and observations in four urban neighbourhoods where expropriation has taken place in Kigali city. Interpretative and statistical analysis of the data reveals some patterns of procedural, recognitional and redistributive justice in the rules dimension. There is no indication of any pattern for other dimensions. This relates to limited budgets of expropriating agencies which insufficiently follow the law. The consequence is the decreased redistributive justice in the compensation and the increase in the displacement effect of expropriation. Although, counter-valuations result in fair compensation, there is limited evidence for good trends of spatial justice in the whole process of expropriation.
\end{abstract}

Keywords: Kigali city; real property; expropriation; valuation; just compensation; spatial justice

\section{Introduction}

Kigali, the capital city of Rwanda, has experienced rapid population growth over the last 20 years, with a growth rate of around $4.0 \%$ per year. Its population is expected to reach 4 million by 2040 [1]. However, such population growth has not been coupled with the provision of basic amenities, services and housing [2] and has therefore resulted in uncontrolled spatial development [3], proliferation of informal settlements and environmental degradation [4]. In 2014, informal settlements occupied $65.8 \%$ of the built-up residential area, hosting $79 \%$ of urban dwellers [1].

In 2007, the Government of Rwanda adopted a master plan providing the legal framework for sustainable and orderly development of Kigali city [5]. The implementation of that master plan significantly affects living conditions of inhabitants in informal settlements. Current urban development schemes consist of upgrading or converting these settlements into modern residential apartments, while people living in high risk zones are being relocated to serviced sites [6]. Other actions consist of developing socio-economic infrastructure in different urban neighbourhoods [7]. These actions have been framed by the government's vision to modernise the country, creating modern and dynamic cities which are more attractive and economically prosperous [8,9]. Nevertheless, their implementation affects negatively the livelihoods of real property owners because they involve processes of expropriation 
of their real properties [10]. This paper discusses expropriation by making reference to the power of government agencies ${ }^{1}$ to interfere in individual real property rights and acquire their properties in order to serve public purposes or social benefits [11]. It refers similarly to government power of eminent domain, compulsory purchase or acquisition of private real property for public interest [12]. The expropriation involves compensation for the acquired properties which can be paid in monetary form or in any other form based on mutual agreement between the expropriating agency and property owners [11,13].

Until 2015, the expropriation law passed in 2007 guided expropriation processes in Rwanda. Its implementation was decried by existing studies to result in unfair compensation which is largely paid in monetary value and dissatisfaction of the expropriated property owners with the paid compensation [14]. The unfair compensation and dissatisfaction with the compensation have also resulted in various conflicts between expropriating agencies and property owners [10,15]. Those studies focus on the implementation of the expropriation law of 2007, which was amended in 2015. They do not discuss in depth different factors which are behind the payment of the unfair compensation and property owners' dissatisfaction. The amended law provides clear procedures which have to be followed by actors in the expropriation in order to determine fair or just compensation value which should be paid to expropriated people. Just compensation value is the value of the expropriated property which is determined at market price [12]. Procedures that may lead to just compensation and which are stated in the current Rwandan expropriation law include the use of updated reference prices, which are determined on the basis of the market prices, for the real properties affected by expropriation and the counter-assessment of the proposed compensation value in the case expropriated people are not satisfied with it [11]. This study therefore explores whether the current expropriation law ameliorates the status quo in the expropriation processes and compensation alongside its implementation in Kigali city. Just compensation is a significant indicator of justice in the implementation of spatial development programmes which affect private property rights $[16,17]$. Within the global context of expropriation, different aspects regarding just compensation are highlighted. They include compliance to national and international norms regarding compulsory acquisition of private property, which implies the rule of law and transparent valuation processes, participation of affected people and their negotiation on fair compensation option and value with expropriating agencies [13,18-20]. Those aspects reflect different patterns of spatial justice, consisting of procedural, recognitional and redistributive.

Proponents of the right to just compensation include Nozick [21] and Rawls [22] who claim for fair compensation when individuals' property rights are infringed through expropriation. Just compensation helps those affected access other material resources and pursue their livelihoods [22-24]. These arguments spell out various patterns of spatial justice required for expropriation to result in just compensation. In this fashion, this paper aims to investigate if there are features of spatial justice in the current Rwandan expropriation law and its implementation processes in Kigali city and whether they result in just compensation. The pursuit of this main research aim is guided by the following research questions:

1. To which degrees are the law, processes and outcomes of expropriation in Kigali city in line with patterns of spatial justice?

2. Is compensation always determined at market value?

3. How satisfied are expropriated people with the received compensation?

4. Does the paid compensation allow expropriated people to acquire other assets and to pursue their livelihoods in the same city?

In next sections, the paper discusses the research framework and methods. Thereafter, findings are presented and discussed. The paper concludes with areas for improvement in both law and expropriation practices in order to ameliorate the status quo of property owners, affected by expropriation.

1 This will be referring to Kigali city and its constituent districts in this study. 


\section{Conceptual Framework}

This study uses an analytical framework of spatial justice, which is broadly referred to the spatial aspects related to social justice [25].This framework is used to derive insights on how different rules and processes pertaining to the use of spatial resources can promote equal opportunities for all categories of people in both access and use of those resources and/or how benefits that accrue from their use are allocated among different users [17]. It is grounded in two theoretical foundations of social justice: deontologism and consequentialism. Deontologism emphasises the role of good rules and processes in advancing justice alongside the management of societal resources and their allocation among different users. Consequentialism claims for equity in the outcomes those rules and processes lead to [26]. In those ethoses, the applied framework comprises of a series of indicators connected to three dimensions of spatial justice, namely rules, processes and outcomes and its three forms consisting of procedural, recognitional and redistributive [17].

As far as expropriation is concerned, assessment of the rules dimension focuses on appropriateness of the expropriation law with regard to procedures actors follow in calculating compensation and involvement of property owners. Direct involvement of property owners is highlighted by Watkins [27] who posits that legal provisions on how all actors in the expropriation interact and bargain on the compensation are important in evaluating whether the applied law promotes spatial justice. For the processes dimension, assessment centres on compliance with the law and how property owners actually participate $[28,29]$. The outcome dimension relates to appropriateness and redistributional aspects of the compensation [30] that should facilitate access to other material resources [27].

As for the patterns of spatial justice, procedural justice relates to fairness of rules and adequacy of each step of the decision-making process while implementing rules [31]. It requires observing just legal principles underling expropriation, collaboration and negotiation among participating actors in order to reach just compensation [32,33]. Recognitional justice seeks compliance to just law [34] and respect of rights of affected people in order to attain just compensation [35]. Redistributive justice consists of remedial schemes, considering the circumstances of the expropriation and recognising the needs of those affected, providing them with just compensation to help reconstitute their livelihoods such as access to housing and basic socio-economic amenities [32]. Appropriate compensation is often determined using market prices [13,36].

Building on these insights, assessment of the expropriation in Kigali city was carried out using a series of indicators measuring spatial justice, with regard to main aspects pertaining to just compensation. These aspects include the relevance of Kigali city and its constituent districts in undertaking expropriation, negotiation with property owners on compensation and their participation in valuation, compensation at market prices and its potential remedy to property deprivation. Table 1 , below, lists indicators used for this assessment. 
Table 1. Matrix for measuring spatial justice alongside the expropriation of the real property in Kigali city.

\begin{tabular}{|c|c|c|c|c|c|c|c|c|}
\hline \multirow{2}{*}{$\begin{array}{l}\text { Forms of Spatial Justice } \\
\text { Under Evaluation }^{2}\end{array}$} & \multirow{2}{*}{ Evaluative Aspect } & \multicolumn{3}{|c|}{ Measurement Indicators and Related Dimension of Spatial Justice } & \multicolumn{4}{|c|}{ Related Research Question } \\
\hline & & Rules & Processes & Outcomes & Q1 & $\mathrm{Q} 2$ & Q 3 & Q 4 \\
\hline \multirow[t]{2}{*}{ Procedural } & $\begin{array}{l}\text { Expropriation is carried } \\
\text { out for public interest }\end{array}$ & $\begin{array}{l}\text { - Presence of legal provisions defining the public } \\
\text { interest as rationale for government agencies to } \\
\text { undertake expropriation. }\end{array}$ & $\begin{array}{l}\text { - Government agencies execute } \\
\text { expropriation solely for public interest. }\end{array}$ & $\begin{array}{l}\text { - Percentage of expropriated people whose properties } \\
\text { were expropriated by government agencies for } \\
\text { public interest. }\end{array}$ & $\sqrt{ }$ & & & \\
\hline & $\begin{array}{l}\text { Neutrality in the } \\
\text { valuation }\end{array}$ & $\begin{array}{l}\text { - Presence of legal provisions for calculating } \\
\text { compensation value by independent valuer. }\end{array}$ & $\begin{array}{l}\text { - Compensation value is calculated by } \\
\text { independent valuer. }\end{array}$ & $\begin{array}{l}\text { - Percentage of expropriated people consenting to the } \\
\text { independency of valuer who calculated their } \\
\text { compensations. }\end{array}$ & $\sqrt{ }$ & & & \\
\hline \multirow{3}{*}{$\begin{array}{l}\text { Procedural, recognitional } \\
\text { and redistributive }\end{array}$} & \multirow[t]{2}{*}{$\begin{array}{l}\text { Negotiation on } \\
\text { compensation and } \\
\text { participation in valuation }\end{array}$} & $\begin{array}{l}\text { - Presence of legal provisions for negotiating } \\
\text { compensation option between expropriating } \\
\text { agency and property owners. }\end{array}$ & $\begin{array}{l}\text { - Consensus on the compensation } \\
\text { option is reached between } \\
\text { expropriating agency and property } \\
\text { owners prior to valuation. }\end{array}$ & $\begin{array}{l}\text { - Percentage of expropriated people who negotiated } \\
\text { compensation with expropriating agency. }\end{array}$ & $\sqrt{ }$ & & & \\
\hline & & $\begin{array}{l}\text { - Presence of legal provisions for negotiating the } \\
\text { compensation value between expropriating } \\
\text { agency and property owners. }\end{array}$ & $\begin{array}{l}\text { - Property owners actively participate } \\
\text { in valuation process and negotiate on } \\
\text { compensation value. }\end{array}$ & $\begin{array}{l}\text { - Percentage of expropriated people who actively } \\
\text { participated in the valuation process and negotiated } \\
\text { compensation value. }\end{array}$ & $\sqrt{ }$ & & & \\
\hline & $\begin{array}{l}\text { Compensation at market } \\
\text { prices }\end{array}$ & $\begin{array}{l}\text { - Presence of legal provisions on compensation at } \\
\text { market prices. }\end{array}$ & $\begin{array}{l}\text { - Compensation is calculated at } \\
\text { market prices. }\end{array}$ & $\begin{array}{l}\text { - Percentage of expropriated people whose } \\
\text { compensation has been calculated at market prices. }\end{array}$ & $\sqrt{ }$ & $\sqrt{ }$ & & \\
\hline $\begin{array}{l}\text { Procedural and } \\
\text { redistributive }\end{array}$ & $\begin{array}{l}\text { Satisfaction with } \\
\text { compensation }\end{array}$ & $\begin{array}{l}\text { - Presence of legal provisions on the processes of } \\
\text { appealing against non-satisfactory expropriation } \\
\text { process. }\end{array}$ & $\begin{array}{l}\text { - Presence of accessible appealing } \\
\text { system for handling claims on the } \\
\text { non-satisfactory compensation value } \\
\text { or option. }\end{array}$ & $\begin{array}{l}\text { - Percentage of the expropriated people who are } \\
\text { satisfied with compensation at first valuation process. } \\
\text { - Percentage of expropriated people who accessed } \\
\text { appealing system and claimed against dissatisfactory } \\
\text { compensation. } \\
\text { - Percentage of expropriated people who are satisfied } \\
\text { with compensation after appealing. }\end{array}$ & $\sqrt{ }$ & & $\sqrt{ }$ & \\
\hline Redistributive & $\begin{array}{l}\text { Access to new properties } \\
\text { using compensation }\end{array}$ & & $\begin{array}{l}\text { - Use of compensation to access other } \\
\text { properties in the close } \\
\text { neighbourhoods. }\end{array}$ & $\begin{array}{l}\text { - Percentage of expropriated people who afford other } \\
\text { properties, using received compensation. }\end{array}$ & & & & $\sqrt{ }$ \\
\hline
\end{tabular}

Adapted from Uwayezu and de Vries [17]

2 Some aspects under evaluation relate to one or more forms of spatial justice. Those forms of spatial justice are therefore presented individually or in combination. 
The assessment indicators are connected to different forms of spatial justice, applied individually or in combination. Procedural justice is required for an effective recognitional and redistributive justice to take place [37], while a combination of all three forms advances just outcomes [30]. The assessment applies two measurement approaches which are commonly used in assessing the effectiveness of systems of land management $[38,39]$. At the dimensions of rules and processes, a Likert scale with five levels, ranging from 'very unjust or dissatisfied' (1) to 'very just or satisfied' (5), is used to evaluate whether the expropriation law promotes fair compensation (see Appendix A). This is based on interpretation of the law by property owners and actors participating in expropriation and their experiences of the law's implementation. Participation of property owners, compliance with the law, compensation at market value and access to other properties are evaluated on the basis of percentages of property owners who are satisfied. Five levels of assessment, from less than $20 \%$ to between $80 \%$ and $100 \%$, were defined. Average scores for each of the assessed forms and dimensions of spatial justice are used in order to draw conclusion on trends of spatial justice in expropriation in Kigali city. Five levels of trends are determined as follows:

1. Very unjust trends: less than 1 score or less than $20 \%$

2. Unjust trends: between 1 and less than 2 scores or between $20 \%$ and less than $40 \%$

3. Relatively unjust/just trends: between 2 and less than 3 scores or between $40 \%$ and less than $60 \%$

4. Just trends: between 3 and less than 4 scores or between $60 \%$ and less than $80 \%$

5. Very just trends: between 4 and 5 or between $80 \%$ and $100 \%$

This evaluation approach is anchored in the matrix of spatial justice in which both just rules and processes result in just outcomes or where rules are unjust but processes are just, the outcomes can be just as well [17]. Alternatively, trends of unjust rules or processes lead to unjust outcomes. In that case, either revision of rules or processes or both is required in order to promote just compensation. The next section presents sources of data for this study and methods that have been applied.

\section{Data Sources and Methods}

\subsection{Study Areas and Sampling}

Kigali city is divided into three administrative districts consisting of Gasabo, Kicukiro and Nyarugenge. The boundary of Kigali city coincides with the boundaries of its constituent districts. It comprises of three main spatial patterns (see the Appendix B): the urbanised, the area under urbanisation and the urban fringe. The study was carried out from January to March, 2018, in four sites, consisting of Rugarama, Agatare, Muhima and Kangondo II (see Figure 1 and Appendix C), located in the urbanised area where expropriation has recently been carried out. 


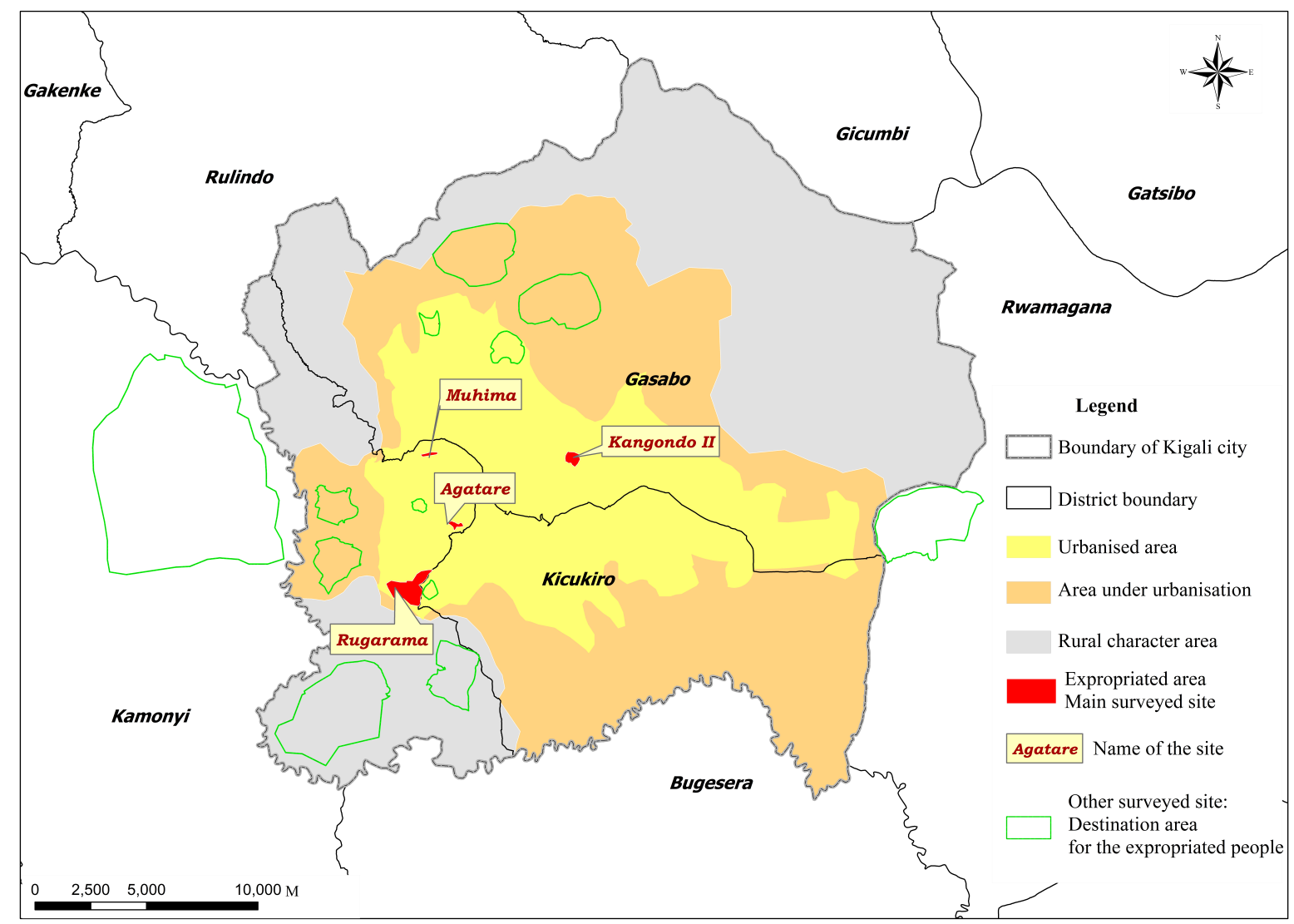

Figure 1. Surveyed sites.Data source: Field work; NISR and CGIS-UR [40].

Both random and purposive sampling were applied in selecting participants to household survey and interviews. Households were selected to participate in the survey using updated cadastral data acquired from the national land registry. In each site, the number of recorded land plots was retrieved. One household was associated with a land plot in order to determine the sample of property owners to participate in the survey. The number of property owners who participated in the survey was selected using the following sampling formula, which is applied in the finite population [41] as follows:

$$
\mathrm{n}=\frac{z^{2} * p(1-p) / e^{2}}{1+\left(z^{2} * p(1-p)\right) / z^{2} * N}
$$

where:

$\mathrm{Z}=$ is the value assigned for the confidence level, which in this case is 1.96 for a margin error of $95 \%$.

$p=$ the desired proportion for the sample size $n$, which is $0.5 . e=$ the tolerable error $(10 \%$ in this study).

$\mathrm{N}$ = population size (for each selected survey site).

The total sample size comprised of 197 respondents, selected among 535 households in four selected sites (see Appendices C and D). The expropriated people in Rugarama and Muhima have resettled in other neighbourhoods. Using the information collected from their former neighbours regarding their current residential areas, these people were tracked, using a snowballing approach in order to include them in the survey. In Rugarama, expropriation was carried out before the amendment of the current expropriation law. This site was included in the study because its inhabitants could provide data that helped to explore patterns of spatial justice in valuation processes and compensation before and after the passage of the current expropriation law. 


\subsection{Data Collection}

\subsubsection{Primary Data}

Primary data for this study were collected through a household survey which was organised for the heads of households. They mainly include men who are the first contact persons on different issues regarding the households, according to the Rwandan culture. In the absence of men, women participated in the survey. They include unmarried women and widows who are heads of households and registered as property owners. The survey questionnaire covered aspects pertaining to perceptions of expropriated people on the effectiveness of the expropriation law and its potential to promote just compensation. These aspects were included in the evaluation matrix, presented in Table 1.

Primary data were also collected through 37 semi-structured interviews organised for different staff working in public and private organisations. Interviewees included decision-makers at district level, members of the district and sector councils, staff at ministry and authority in charge of infrastructure and housing development, researchers at the Institute of Policy Analysis and Research (IPAR-Rwanda), the Rwanda Governance Board (RGB) and the University of Rwanda (UR). Staff of the ministry of justice and the office of the Ombudsman, property valuers, local government leaders, urban planners and land managers participated also in interviews. These informants were selected because they participate either in planning and implementing different activities related to expropriation or carry out research on the implementation of rules related to land management in Rwanda and issues of good governance. Interviews covered various topics including the effectiveness of the expropriation law to promote just compensation, planning and implementation processes of the expropriation, collaboration between actors in expropriation, calculation of compensation value and the management of related conflicts.

Focus group discussions (FGD) were organised in each of the surveyed site, with heads of households and local leaders for validating data collected from the household survey and collecting additional data on the implementation of the expropriation law. Field observations were also organised in order to collect data on characteristics of properties which are being expropriated or being developed in the resettlement areas for the expropriated people, the availability of the basic amenities in those areas and the ongoing urban (re)development projects in the areas where the expropriation was carried out.

\subsubsection{Secondary Data}

Secondary data on expropriation processes were collected from various documents and media records. Those documents include the expropriation law, research papers and reports on expropriation, reference lists for real property prices established by the Institute of Real Property Valuers of Rwanda (IRPVR) and districts, for determination of the compensation value. Others are compensation rolls, valuation and counter-valuation reports held either by the expropriated people or real property valuers. Data on recent land prices were used to assess the degree to which reference prices for calculating the compensation are consistent with market prices. They were extracted from land transaction proofs held by land managers and property owners. Media resources include video and online newspapers articles on expropriation processes and compensation option.

\subsection{Data Analysis}

Data analysis included the transcription of recorded information through interviews and household surveys. Transcripts were organised into seven themes, in table format. These include the purpose of expropriation; collaboration between the expropriating agencies, real property valuers and property owners; independence of the valuers; calculation of compensation value; compensation satisfaction; appeal processes; and use of compensation in accessing other properties. Validation of and consistency check between all collected data were performed using triangulation approach [42]. As the 
evaluation uses the measurement scale with five levels, the recorded scores and other quantitative data were organised in table format using excel. SPSS was used to perform descriptive and inferential statistics. Excel was used to generate graphical illustrations. Spatial statistics and map algebra tools of ArcGIS helped in producing qualitative maps on mobility of the expropriated people and their access to basic amenities. The next section presents and discusses results.

\section{Results and Discussion}

Results are presented and discussed in the same flow as the structure of the evaluation framework.

\subsection{Patterns of Spatial Justice in the Law and Processes of Expropriation and Compensation}

Table 2 presents general trends of spatial justice in the expropriation in Kigali city, based on the assessed aspects, in connection to related form(s) and dimension of spatial justice. Generally, good trends of spatial justice are observed in the current expropriation law. However, such trends are not observed in the implementation processes of the law and its outcomes. Discussion of these trends centres on recorded score for each of the assessed aspects.

In Table 2, the effectiveness of the expropriation law, related processes and outcomes were generally evaluated by putting emphasis on the rationale for the expropriation and drivers for just compensation. Driving factors for just compensation include participation of property owners in expropriation and negotiation on compensation option/value, valuation by the independent valuer, appeal process and compensation at market value. Features of spatial justice pertaining to these aspects and related scores are discussed below.

\subsubsection{Procedural Justice and Compliance Dilemma}

In this sub-section, procedural justice centres on the effectiveness of the expropriation law in condoning intervention of Kigali city and its constituent districts in carrying out expropriation for public interest and their neutrality in calculating compensation. Average scores for the two aspects are 3.8 and 3.7 out of 5 in the law, 1.3 and 2.4 out of 5 in the processes, for expropriation carried out before and after 2015. Those scores reveal good trends of procedural justice in relation to the law and its deficiency in the processes. Result is a low level of satisfaction on the outcomes. Driving factors can be interpreted from the lens of involuntary non-compliance [44], especially when public agencies lack necessary capacity to comply with the law and therefore implement it inefficiently.

\subsubsection{The Fallacy of Public Interest}

The expropriation law [11] grants government agencies the power of eminent domain and to intervene in expropriation for different activities aimed at developing public amenities. However and unlike the previous law, the current law, in article 7, classifies activities pertaining to the implementation of master-plans among issues in public interest. Article 7 has been misinterpreted by public agencies which initiate expropriation for all kinds of projects aimed at implementing master-plans [10]. In other words, the power of eminent domain has not just been used in the public interest but also in terms of private interests, without prior consultation with property owners. According to property valuers and owners who participated in the interviews, that practice is not appropriate as they argue:

"The law does not grant Kigali city and its constituent districts the power to initiate the expropriation for a real estate agency whose projects consist of developing apartments for rent or sale ${ }^{3} . "$ 
Table 2. Trends of spatial justice within the expropriation law, its implementation practices and outcomes.

\begin{tabular}{|c|c|c|c|c|c|c|c|}
\hline \multirow{2}{*}{ Forms of Spatial Justice } & \multirow{2}{*}{ Evaluated Aspect } & \multirow{2}{*}{$\begin{array}{c}\text { Period of } \\
\text { Expropriation }\end{array}$} & \multicolumn{2}{|c|}{ Mean Score ${ }^{b}$} & \multirow{2}{*}{ Sig*. (2-tailed) } & \multicolumn{2}{|r|}{ Score on Outcomes and Comments } \\
\hline & & & Law & Processes & & Score in $\%^{a}$ & Comments \\
\hline \multirow{2}{*}{ Procedural justice } & Expropriation for public interest & $\begin{array}{l}\text { Before } 2015 \\
\text { After } 2015\end{array}$ & $\begin{array}{l}2.95 \\
3.19\end{array}$ & $\begin{array}{l}1.16 \\
2.46\end{array}$ & $\begin{array}{l}.001 \\
.001\end{array}$ & $\begin{array}{l}0 \% \\
51 \%\end{array}$ & People whose properties were expropriated for public interest \\
\hline & $\begin{array}{l}\text { Neutrality in calculating the } \\
\text { compensation }\end{array}$ & $\begin{array}{l}\text { Before } 2015 \\
\text { After } 2015\end{array}$ & $\begin{array}{l}4.82 \\
4.25\end{array}$ & $\begin{array}{l}1.50 \\
2.39\end{array}$ & .001 & $\begin{array}{l}14 \% \\
24 \%\end{array}$ & $\begin{array}{l}\text { People whose compensation value was calculated by an } \\
\text { independent valuer }\end{array}$ \\
\hline \multirow{5}{*}{$\begin{array}{l}\text { Procedural, recognitional } \\
\text { and redistributive }\end{array}$} & Negotiation on compensation option & $\begin{array}{l}\text { Before } 2015 \\
\text { After } 2015\end{array}$ & $\begin{array}{l}2.63 \\
2.33\end{array}$ & $\begin{array}{l}1.16 \\
1.54\end{array}$ & $\begin{array}{l}.001 \\
.001\end{array}$ & $\begin{array}{l}0 \% \\
0 \%\end{array}$ & People who negotiated compensation option \\
\hline & Participation in valuation & $\begin{array}{l}\text { Before } 2015 \\
\text { After } 2015\end{array}$ & $\begin{array}{l}2.57 \\
2.30\end{array}$ & $\begin{array}{l}1.21 \\
1.51\end{array}$ & $\begin{array}{l}.001 \\
.001\end{array}$ & $\begin{array}{l}0 \% \\
0 \%\end{array}$ & People who participated in calculating the compensation \\
\hline & $\begin{array}{l}\text { Valuation and compensation at } \\
\text { market prices }\end{array}$ & $\begin{array}{l}\text { Before } 2015 \\
\text { After } 2015\end{array}$ & $\begin{array}{l}4.93 \\
4.91\end{array}$ & $\begin{array}{l}1.41 \\
1.74\end{array}$ & $\begin{array}{l}.001 \\
.001\end{array}$ & $\begin{array}{l}18 \% \\
14 \%\end{array}$ & $\begin{array}{l}\text { People whose compensation was calculated at market prices } \\
\text { (First valuation) }\end{array}$ \\
\hline & \multirow[b]{2}{*}{ Satisfaction with compensation } & Before 2015 & - & & $\begin{array}{l}- \\
-\end{array}$ & $\begin{array}{l}18 \% \\
39 \%\end{array}$ & $\begin{array}{l}\text { People who are satisfied with compensation at first valuation } \\
\text { People who are satisfied with compensation after counter-valuation } \\
\text { (good trends through increase in the level of satisfaction) }\end{array}$ \\
\hline & & After 2015 & - & & - & $\begin{array}{l}14 \% \\
48 \%\end{array}$ & $\begin{array}{l}\text { People who are satisfied with the compensation at first valuation } \\
\text { People who are satisfied with the compensation after } \\
\text { counter-valuation (good trends through increase in the level of } \\
\text { satisfaction) }\end{array}$ \\
\hline Redistributive & $\begin{array}{l}\text { Access to other properties using } \\
\text { the compensation }\end{array}$ & $\begin{array}{l}\text { Before } 2015 \\
\text { After } 2015\end{array}$ & $\begin{array}{l}- \\
-\end{array}$ & - & - & $\begin{array}{l}8 \% \\
9 \%\end{array}$ & People who afford other properties in the close neighbourhoods \\
\hline
\end{tabular}

*: The significance levels of differences between scores at rules and processes dimensions are checked using T-Test at $\mathrm{P} \leq 0.01$; $^{\mathrm{a}}$ : The evaluation is based on percentages of property owners who participated in the action or expressed their satisfaction about its outcome. ${ }^{\mathrm{b}}$ : Good trends of spatial justice are identified in the expropriation law (more than average score as the maximum is 5) but they are deficient in its implementation processes (very low scores. Data source: Household survey and interviews; Land transaction reports and compensation reference prices list, 2017-2018 [43]. 
The practice of public agencies to use the power of eminent domain in carrying out the expropriation for private interest records low scores in three dimensions of spatial justice. This practice is decried for disguising patterns of unfair compensation, as stated by participants in the household survey and interviews. Property owners perceive that their rights are not recognised by districts which do not allow them negotiating just compensation with investors. Private property valuers raised the same concern. They find inappropriate for districts to carry out the expropriation for private investors, while the latter should directly negotiate with property owners, as follows:

"District authorities use the expropriation for public interest as a strategy to attract private investors. They initiate the expropriation which may result in paying low compensation, while its purpose is for private investment. However, if the investors negotiate with property owners, the compensation value may be higher. Paying low compensation can be a ground for collaboration between districts and investors who contribute in implementing socio-economic development programmes some of which are counted while evaluating the performances of the districts.".

However, other respondents interpreted that practice differently. High and local levels government authorities rejected these allegations. They do not find it unjust for Kigali city and its constituent districts to carry out expropriation on behalf of private investors. They contend that:

"Letting property owners negotiate the compensation with the investors can result in long processes, high speculation on property prices and demand for excessive compensation. This can result in either delay in the start of the project of the investors or its abandon. Those investors create jobs for the public. Some of them contribute in mitigating the shortage of modern residential buildings ${ }^{5}$."

These are the main grounds for Kigali city and its constituent districts to assist private investors in acquiring land, because those investors contribute in the development of Kigali city and job creations. Proponents of this idea maintain that:

"If Kigali city and its constituent districts carry out the expropriation for private investors and property owners are not satisfied with the compensation, they can appeal and proceed with the counter-valuation. The law is clear ${ }^{6} . "$

Actually, the pursuit of just outcomes entails observing the law so that local community can trust the authorities [38]. Putting it clear, the authorities should play a role of mediators between investors and property owners in negotiating just compensation that fairly values the affected properties. Calculating a just compensation may also be a concern when the expropriation is carried out for public interest. It is hence necessary to comprehend how this process which requires neutrality of expropriating agency in the valuation is undertaken.

\subsubsection{Lack of Neutrality in Calculating Compensation}

According to the expropriation law, the calculation of just compensation is undertaken by an independent valuer, registered under the board of the Institute of Real Property Valuers in Rwanda (IRPVR). Property owners expect property valuers to be independent and to calculate compensation freely from the interference of expropriating agencies. However, most of the expropriated people decry the lack of independence of valuers who carry out valuations on behalf of public agencies. Although, legal provisions on this aspect have a very good score, this is very low on neutrality in the current and previous practices, hence the outcome. In fact, valuation for compensation is carried out by valuers

4 Interviews with property valuers.

5 Interviews with local government leaders, members of district council, decision makers at MININFRA and high level authority and the Ministry of Justice. The budget for the expropriation is always estimated, without prior survey for the affected proprieties.

6 Ibid. 
who are hired either by Kigali city or its constituent districts, through annual framework contract for valuation services. Those valuers are criticised by property owners for having developed patronage relationships with their employers. They seldom use updated reference prices in order to palliate to insufficient budgets those agencies may face, in the case the cost for expropriation becomes higher than estimated in budget plans ${ }^{7}$. Inadequacy of compensation can often be exacerbated by the superior bargaining position of public agencies which carry out the expropriation. However, recognising the rights of property owners to participate in the expropriation and observing its redistributive feature can be aligned with the demand of just compensation. This requires not to separate the three forms of spatial justice, consisting of procedural, recognitional and redistributive justice [37] in the pursuit of fair compensation.

\subsubsection{Trends of Procedural, Recognitional and Redistributive Justice}

Trends of the three forms of spatial justice are explored within the expropriation law, its implementation practices and the compensation (outcomes), focusing on specific aspects. Those include recognition of rights of property owners to participate in expropriation, to negotiate on compensation options and values, the calculation of compensation at market price and satisfactory and just compensation. Scores for these aspects reveal good trends of spatial justice in the law dimension, with mean scores of 3.3 and 3.1 out of 5 , while processes show very low scores of 1.2 and 1.5 out of 5 , in expropriations carried out before and after 2015 as observed in Table 2. The levels of satisfaction on the outcomes were very low for both periods.

\subsubsection{Negotiation on the Compensation Option/Value and Participation in Valuation}

Negotiation on compensation option and participation in the calculation of the compensation value are ultimately the rights of property owners and drivers for fair compensation [32]. However, these features of spatial justice which advance a fair redistribution and guarantee just outcomes are not well expressed in Rwandan expropriation law. The law grants independent valuers the power to undertake valuations in the presence of property owners. Yet, there is no clause endorsing the participation of property owners in processes such as checking reference prices or asking details on how compensation is calculated. It grants property owners the right to choose among two compensation options: "in cash or in kind." But the decision on the option or form of compensation is made by expropriating agencies, whether the expropriation is carried out for public or private interest. The law opens room for negotiation when private investors aim at implementing the master-plans. If negotiations between property owners and investors fail, expropriation can be carried out as an act of public interest (Article 6). This clause was not respected in two cases of expropriation, namely Rugarama and Kangondo II. Actually, the expropriation was carried out for development of residential apartments by private investors. For the compensation option, property owners in Kangondo II have complained against the decision of Kigali city and Gasabo district to resettle them in shared residential apartments, without prior consultation. Nevertheless, the law (article 35) provides the room for the expropriator to negotiate with property owners and mutually agree upon compensation options. For the authorities in Kigali city and Gasabo district, it is appropriate to decide on the compensation option for those property owners, as follows:

"Keeping paying money as compensation option to the expropriated people thrives informal settlements in Kigali city and its outskirts. Property owners whose houses are of poor quality receive little money as compensation. They move to urban fringes where they build up new poor quality housing and

7 Interviews with urban planners and land managers. 
henceforth contribute to the spread of slums, which are being cleared alongside the implementation of the current master plan. The practice for compensation in cash should stop ${ }^{8,9} . "$

Though these authorities justify the relevance of their decisions in counteracting the proliferation of slums, the expropriated people ${ }^{10}$ and low level government officers ${ }^{11}$ argue that rights of property owners to negotiate on the compensation option should be respected. That question of non-participation of property owners in making some decisions that affect their livelihoods is also echoed in reports published on service delivery, good governance and performances of local governments $[45,46]$. This correlates with findings on low trends of spatial justice in the aspect of participation in expropriation and negotiation on compensation in this study. Very low scores are recorded at the dimensions of rules, 2.6 and 2.3 out of 5 and processes, 1.18 and 1.52 out of 5, (before and after 2015 respectively) and therefore in the outcomes. When the expropriation is undertaken outside the bargaining arena, its fairness can be questioned. It can further be assessed on the basis of compensation value which has to be calculated at market prices, when expropriating agencies behold the affected property owners [32].

\subsubsection{Compensation at the Market Prices}

Like the previous law, the current expropriation law establishes clear procedures for determining fair compensation at market prices. An updated list of the reference prices for the land, crops and trees has to be annually established by IRPVR [15] and approved by relevant organs [47]. For other properties such as buildings, valuation methods such as the cost approach, comparable sales approach and income approach have to be applied. However, as pointed out in Section 4.1.1.2, expropriated people have decried the fact that valuers who are hired by expropriating agencies often do not use market prices or appropriate valuation methods so that the compensation value becomes unfair. In other words, valuation processes and outcomes show no good trend of spatial justice.

A new list of reference prices, which is in use since 2017, was established at the end of 2016 [43]. Prior to this, the calculation of compensation repeatedly resulted in low values due to the use of outdated list of reference prices, determined in 2008 [48]. When no updated reference list price exists, property valuers should look for recent sale prices for land or use other valuation methods in calculating compensation at market value. However, compliance is often limited due to lack of independence (Section 4.1.1.2) with valuers aiming at minimising the expropriation costs for agencies they work for. Those agencies execute different urban development projects, requiring huge amounts of public funds. Some projects are often part of performance contracts signed with higher levels of government as a performance management tool in monitoring how districts perform in achieving long-term socio-economic development goals. Calculating compensation below the market prices is attributed to budget constraints when those agencies intend to meet goals pertaining to public interest and achieve their performances, without due consideration of private property rights. That practice was repeatedly made by participants to this study:

"District authorities feel a need to implement some urban development projects for their best appraisal, even though the cost for the expropriation has not been secured enough ${ }^{12}$."

This argument was largely repeated in the interviews with members of the district councils, urban planners, land managers, staff at the office of Ombudsman, researchers at UR and RGB and

8 Interview with land manager and urban planner in Gasabo district.

9 https://www.newtimes.co.rw/section/read/228299.-http://igihe.com/amakuru/u-rwanda/article/abazimurwa-muribannyahe-barashaka-ingurane-y-amafaranga-aho-kubakirwa-inzu,-https://www.kigalitoday.com/amashusho/kt-tv/ article/bannyahe-abaturage-ntibishimiye-kwimurwa-badahawe-ingurane-y-amafaranga,- Audio records from TV1, on expropriation in Kangondo II; March 2018.

10 Household survey.

11 Ibid. as 7.

12 Interviews with members of district council and property valuers. 
property owners and recently published report on the issues of good governance [46]. Inequity in calculating the compensation value can substantively influence aspect of satisfaction which derives from the feeling of the expropriated people on fair compensation. Although it is obvious to consider all factors, such as the fairness of the whole process of expropriation, including participation, negotiation, prompt payment of the compensation and its use to acquire new assets which influence the satisfaction of the property owners on the compensation [49], satisfaction aspect was exclusively assessed in this study on basis of the experience of the expropriated people on the use of the market prices while calculating their compensation.

\subsubsection{Satisfaction on the Compensation Value}

Some of the expropriated people evaluate their satisfaction on the basis of calculating their compensation at market prices and access to other properties after expropriation. In this study, the degree of satisfaction was evaluated in two stages: first valuation and counter-valuation. People who are satisfied at the first valuation represent $18 \%$ and $14 \%$ of expropriated property owners before and after 2015 respectively (Figure 2 ) and are mainly poor groups whose income per month ranges between 70-150 USD (see Appendix D).

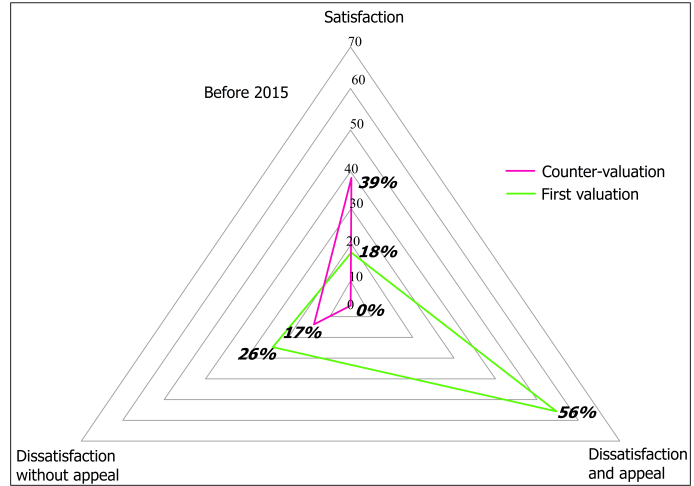

(a)

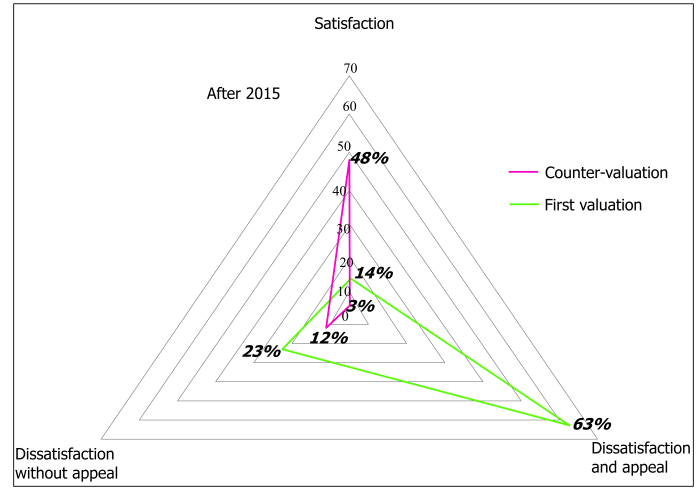

(b)

Figure 2. (a) Trends in satisfaction and dissatisfaction on the compensation before 2015; (b) Trends in satisfaction and dissatisfaction on the compensation after 2015. Data source: Household survey.

Those people do not compare compensation value to the market value. The quality of their buildings, some of which are located in wetlands, is generally poor as Figure 3 shows.
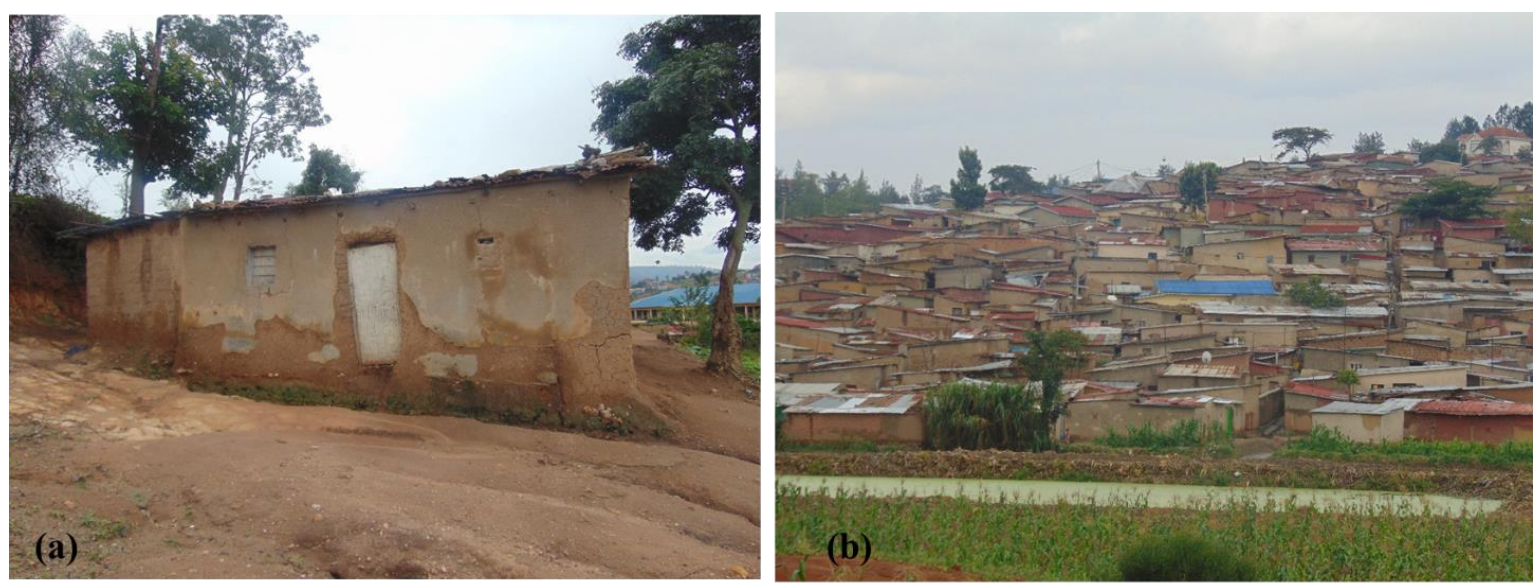

Figure 3. (a) Poor housing quality for the expropriated poor groups in Kangondo II; (b) Location of some of the expropriated residential buildings in the wetland area. Data Source: field observations. 
Those buildings on Figure 3 do not attract private buyers. Property owners do not have reference prices from the open market, which can be a basis for dissatisfaction with the compensation value. They rely on calculated compensation value to acquire other properties outside the city where the prices may be affordable and accept compensation at the first valuation. However, a high number of other people are not satisfied at the first valuation (56\% and 63\% before and after 2015 respectively; see Figure 2). Through appealing, those people used the counter-valuation process which resulted in increased satisfaction (at 39\% and 48\% before and after 2015 respectively, see Figure 2). The general levels of satisfaction reached $57 \%$ and $62 \%$ for people who were expropriated before and after 2015, by counting the outcomes of first valuation and counter-valuation. However, those figures still reveal low levels of satisfaction on compensation in similar ways as previous studies $[15,45,50]$.

The level of satisfaction increases through the process of counter-valuation which is provided in the expropriation law. People who can afford it engage the services of private valuers who carry out a counter-assessment for the value of their properties, submit the resulting report to expropriating agencies in order to appeal for just compensation. However, the outcome of the counter-valuation may sometimes be unsatisfactory for some people who appeal (see Figure 2). This happens when negotiations with expropriating agency do not result in paying all amount of money which is claimed through the counter-valuation report. The amount might have been disproportionately increased by the hired private valuers. The revision of the counter-valuation report can therefore result in dissatisfaction for the expropriated people, though the compensation value has increased.

Dissatisfaction on the compensation at the first valuation is driven by speculation on reference prices which are used in calculating the compensation. This has become a factor for property owners to appeal against the first valuation. For example, during the expropriation in Rugarama in 2014, there was high speculation on land price which was being used in calculating the compensation by valuers hired by expropriating agency. Initially, valuers intended to use very low reference price, which was twice rejected by property owners, until negotiations reached an agreement to calculate compensation at market value. During bargaining, land price increased from 7.7 USD to 12.2 USD $^{13}$, through 9.5 USD per square meters.

Currently, claims against the first valuation are also frequent. Expropriated people find reference prices set by the IPVR to be low, compared with market prices. As finding of this study, there are clear dissimilarities between the two prices, based on land transactions records collected from different land management offices in Kigali city. Those dissimilarities are presented in Table 3, below:

Table 3. Comparison between the land prices in 19 locations and the current reference prices in the USD.

\begin{tabular}{cccccccccc}
\hline Year & $\begin{array}{c}\text { Reference Price } \\
\text { (average) }\end{array}$ & $\begin{array}{c}\text { Market } \\
\text { Prices }\end{array}$ & Difference Sig. & $\begin{array}{c}\text { Reference Price } \\
\text { (maximum) }\end{array}$ & $\begin{array}{c}\text { Market } \\
\text { Prices }\end{array}$ & Difference & Sig. \\
\hline 2017 & 5.40 & 9.72 & 4.32 & $.054^{*}$ & 8.22 & 9.72 & 1.49 & .697 \\
2018 & 5.40 & 12.16 & 6.76 & $.002^{* *}$ & 8.22 & 12.16 & 3.93 & .116 \\
\hline
\end{tabular}

Asterisk means significant difference level of reference price compared to market prices (Dunnett's $t$ test), as follows: ${ }^{*} \mathrm{P} \leq 0.1 ;{ }^{* *} \mathrm{P} \leq 0.01$. Data source: Household surveys; Land transaction reports and compensation reference prices list $2017-2018$ [43].

In Table 3, averages for the mean and maximum reference prices in use (established in 2016 and in use since 2017) for compensation are compared to mean land prices (at open market) for two consecutive years in 19 localities. The current mean reference prices are even very low compared to market prices recorded two years ago. Land prices in 2017 were slightly significantly different from the mean reference price in use at $\mathrm{P} \leq 0.1$ while those prices are very significantly different at $\mathrm{P} \leq 0.01$, in 2018. Contrasts between the reference prices in use for the calculation of the compensation and the market prices are well presented in Figure 4.

13 Exchange rate of 684 Rwandan francs for 1USD, in April 2014. Data source: valuation rolls for the expropriated people in Rugarama site. 


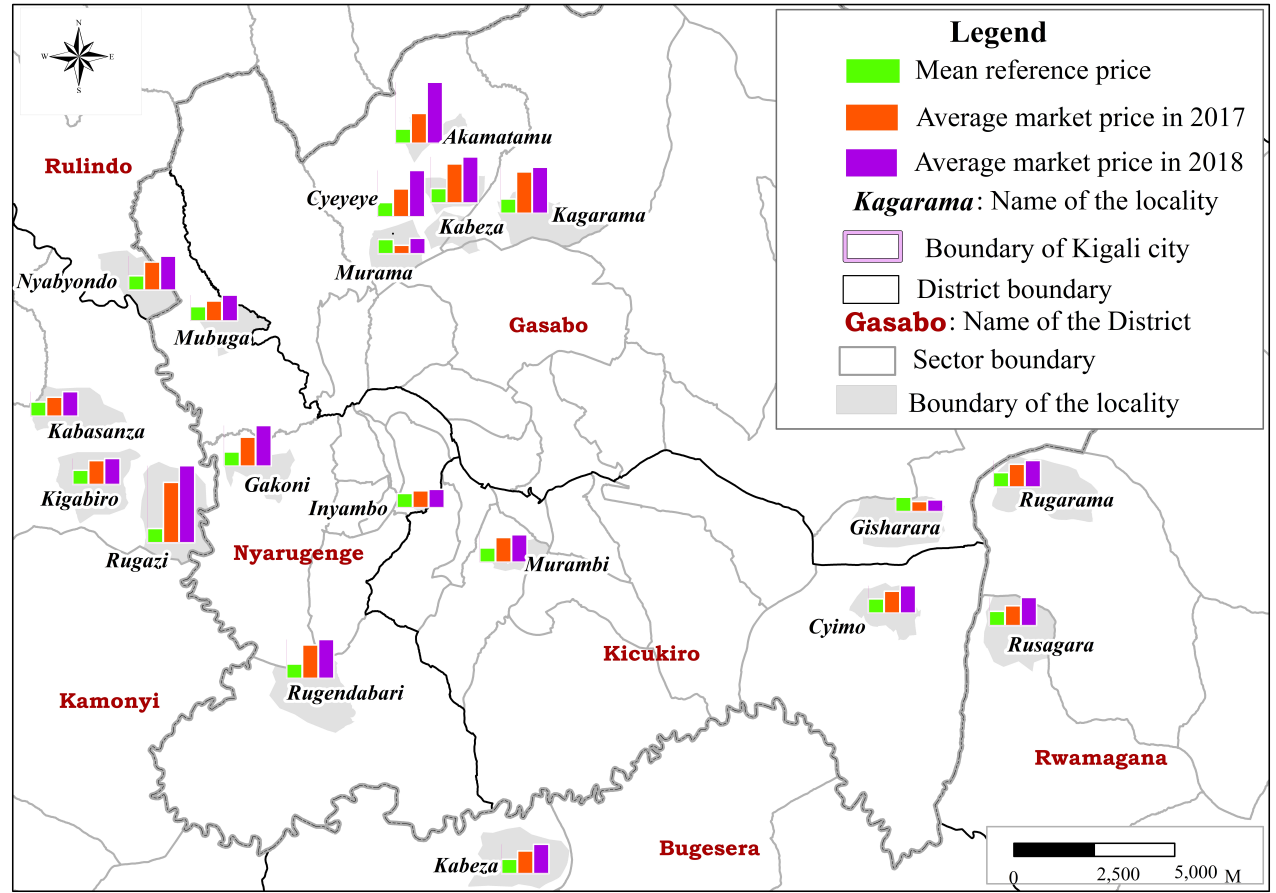

Figure 4. Comparison between mean reference price for expropriation and the market. Data sources: Household surveys; Land transaction reports and compensation reference prices list 2017-2018 [43].

Figure 4 shows that in most of the 17 localities, the mean reference prices which are mostly used for the calculation of the compensation are lower than the market prices in 2017 and 2018. Those prices are higher than the market prices for the same period in two (2) localities only (Murama and Gisharara). If the maximum prices are compared to market prices in the same years, results rather reveal some positive trends in some localities, as Figure 5 shows:

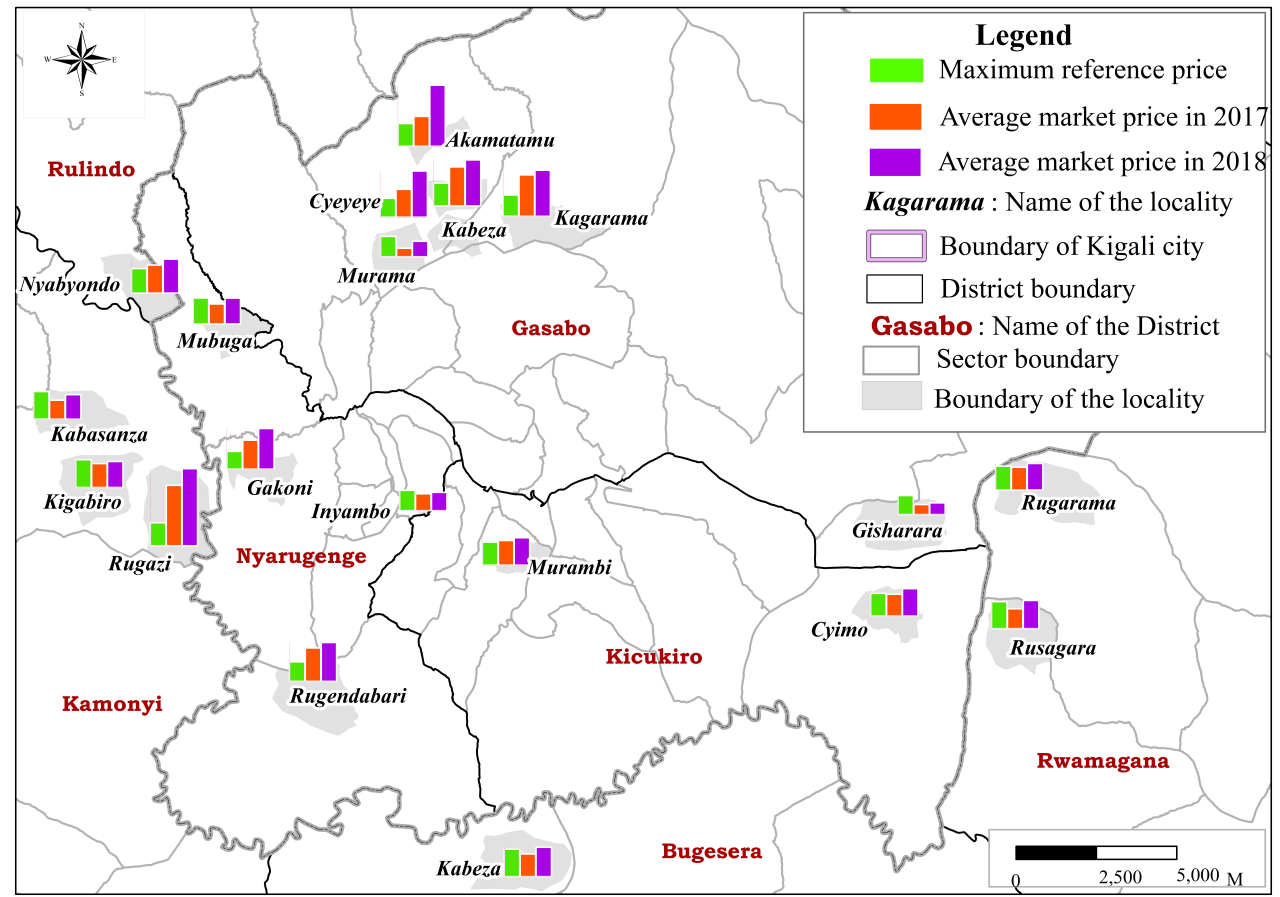

Figure 5. Comparison between maximum reference price for expropriation and the market. Data sources: Household surveys; Land transaction reports and compensation reference prices list 2017-2018 [43]. 
In Figure 5, the maximum reference price is greater than the market prices for the year 2017 in some localities. However, it is still lower than the market price for the year 2018 in most localities. The results of statistical test, presented in Table 3, show that the maximum reference price is not very significantly different from the market prices during the two years. Yet, the former remains lower than the latter. Those differences explain the reasons why most property owners complain against first valuation, which applies the established reference prices. A clear instance shows that in one of the counter-valuation reports, a reference price equivalent to 17.50 USD per square meter of land was in use in the first valuation carried out in February, 2018. During that period, the latest sale price which was used as reference price for the counter-valuation was equivalent to 33.82 USD. Yet, most of property valuers are aware of constant changes in prices of real property in Kigali city (see Appendix E). These changes are attributed to speculation regarding property prices, since prices have constantly increased from 2008, following the implementation of Kigali city master-plan. It has involved acquisition of large tracks of land and related assets through expropriation or private land transactions. The inflation is also among driving factors for speculation in real property prices [15]. Expropriated people contribute to such speculation in the urban fringe, where they buy land for housing development. This speculative property market and perpetual increase in prices should entail calculation of compensation values using references from recent sales and appropriate valuation approaches such as the replacement cost.

Counter-valuation is not used for claiming just compensation for land only. It applies also for re-calculating the compensation for buildings when its size was not well measured, all its components and their quantities underestimated or cost for the excavation works not counted in the compensation values. One way to understand the degree to which counter-valuation promotes just compensation is to examine figures which are presented in Table 4 . They show increase in the geometric mean of compensation values for 93 expropriated people who used counter-valuation to receive just compensation.

Table 4. Variation in compensation values, based on first and counter-valuation.

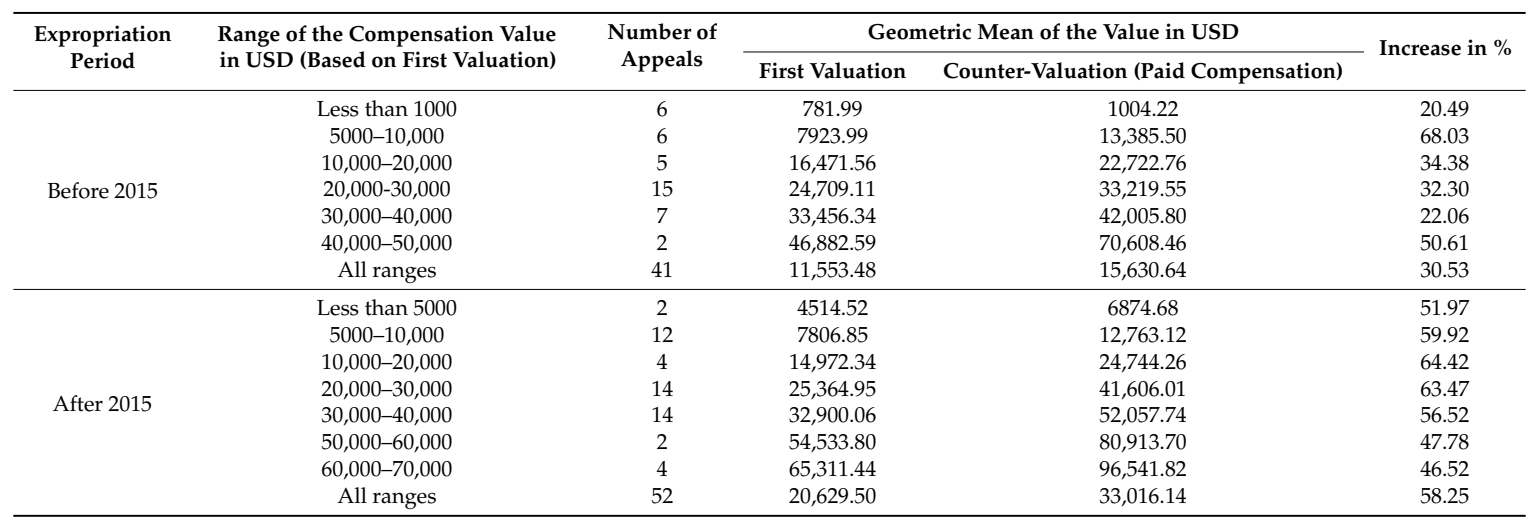

Data source: Valuation reports from private property valuers and expropriated property owners.

Table 4 shows a high increase in the compensation value, by comparing the outcomes of the first valuation and the counter-valuation, for properties owners who were expropriated in different urban neighbourhoods before and after 2015. The increase in compensation is driven by observance and verification of the market value component in the process of counter-valuation by property owners, the hired independent valuers and the expropriating agency. The use of actual market value is at the heart of surpluses to the first value, which was previously calculated by a valuer hired by the expropriating agency. Through process of counter-valuation, Kigali city and its constituent districts observe procedural, recognitional and redistributive justice and negotiate with property owners in order to reach a consensus on just compensation. However, this only works for people who are relatively young (less than 55 years old, see Appendix D), educated and whose incomes are moderate 
or high help them afford the cost of counter-valuation. They search for market information on property prices, use it as ground for appeal and receive just compensation.

The cost of appeal disincentives poor people from engaging with counter-valuation processes. Those people find very expensive hiring a private valuer for around $68 \mathrm{USD}^{14}$, beside their uncertainty about its outcome. They therefore accept compensation calculated at the first valuation, even though they may not be satisfied. The inability to appeal is also linked to low levels of education or illiteracy, because they are not well informed about property markets. This is also true for older people or widows who may be sceptical about outcomes of counter-valuation. They also find it difficult to challenge government actions (see Appendix F). Perception is also part of the problem. Many old and illiterate people argue that the introduction of the long lease tenure system allocates the ownership of land to the government which can repossess it any time. Despite this misconception, the current expropriation law recognises all peoples rights to just compensation, regardless their tenure statuses. Beside the just compensation which is discussed above, redistributive pattern of just compensation should constitute of remedial schemes and promote the replacement of the affected people in similar living conditions as before the expropriation. This pattern is explored through the opportunity of the expropriated people to invest the received compensation in replacing the expropriated properties in close neighbourhoods, relative to the areas they move from.

\subsection{Paucity of Redistributive Justice}

The redistributive pattern of spatial justice centres on access to basic needs such as housing, infrastructure and social services [51]. This pattern was exclusively assessed by probing whether the paid compensation establishes financial means for expropriated people to access other properties in their neighbourhoods or close vicinity and basic socio-economic amenities. General trends show little likelihood for most of the expropriated people to stay in the core urban area due to the high perceptions of eviction or expropriation in the low income neighbourhoods where prices for new properties are affordable.

\subsubsection{Access to New Properties in the Close Vicinity}

The replacement value for the expropriated property is among evaluative metrics which can be used in assessing whether compensation helps the affected people in acquire new properties and replace them in similar socio-spatial positions. The cost for housing is an important factor in pursuing the same lifestyle in the close vicinity to their previous homes. Notwithstanding the received right compensation, after counter-valuation, is often insufficient to acquire new properties in neighbourhoods close to where they had been living. This is due to high levels of speculation in real property prices. The imbalance between the compensation value and replacement cost exerts a displacement effect on the expropriated people. They therefore migrate to the urban fringe and surrounding rural areas where land and housing prices are lower than in the inner city, where they had moved from. Figure 6 shows trends of prices for the new properties, compared to the paid compensation.

The analysis of differences between compensation and prices for new properties shows positive correlation between the costs for new properties and the received compensation. However, the average cost of a new property such as building is slightly lower than compensation paid, as seen in left side of Figure 6, because those properties are acquired outside of the city. The right side of the figure shows negative correlation between the costs for new properties and location. The prices decrease and new properties become affordable as the distance from the inner city toward the urban fringes increases. In other words, prices for new properties decrease when expropriated people move from the inner city (location 1 where they have been living) towards the rural urban fringes (location 3), through the zone under urbanisation (location 2). Those correlations are presented in Table 5, below.

14 Exchange rate of 883.23 Rwandan francs for 1 USD. 


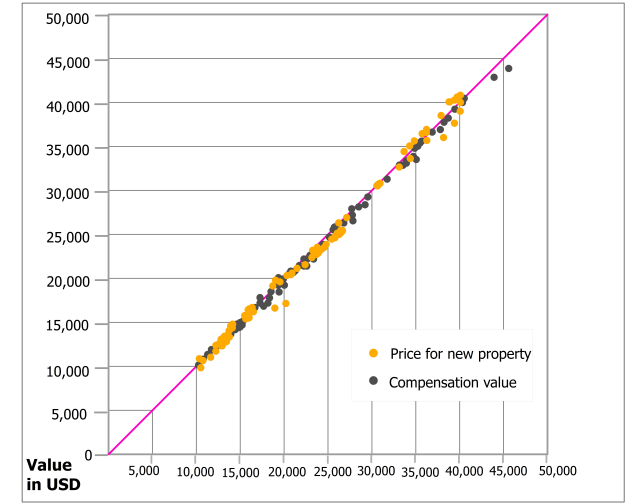

(a)

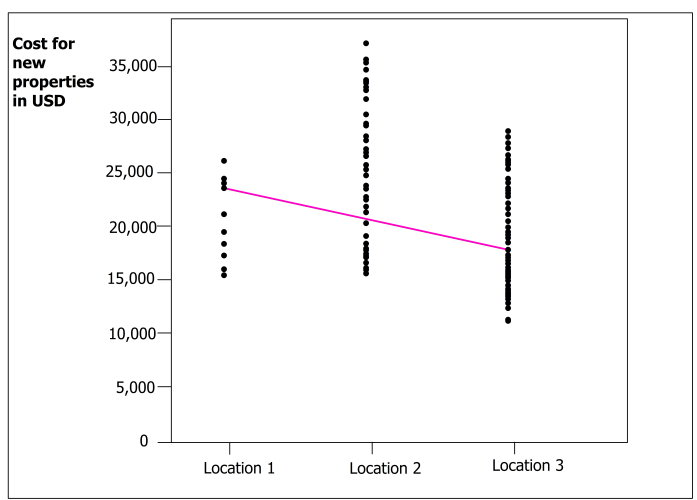

(b)

Figure 6. (a) Trends in cost of new buildings, compared to compensation value; (b) Trends in prices of new buildings, according to the location of resettlement for the expropriated people. Data sources: Households survey and field observations.

Table 5. Cost of new properties, compared to the compensation.

\begin{tabular}{cccccc}
\hline Location & \multicolumn{1}{c}{ Number Mean Value for Compensation } & Mean Prices for New Property & Correlation Coefficient & Sig. \\
\hline 1 & 9 & $23,207.04$ & $20,920.45$ & $.695^{*}$ \\
2 & 29 & $26,467.37$ & $29,580.45$ & .038 \\
3 & 33 & $20,300.46$ & $16,705.15$ & .001 \\
\hline$*$
\end{tabular}

*. Correlation is significant at $\mathrm{P} \leq 0.05$ level (2-tailed); ${ }^{* *}$. Correlation is significant at $\mathrm{P} \leq 0.01$ level (2-tailed). Data source: Household surveys and land transaction reports.

Location 1 is part of the urban core, where few of expropriated people (6\% and $3 \%$, before and after 2015 respectively) have acquired other properties. Prices correlate as the cost for new properties is relatively lower than the compensation. The low prices for buildings in location 1 are linked to risks of eviction that property owners perceive because that location is within informal settlements which can be cleared any time, alongside the implementation of the master plan of Kigali city. Therefore, property owners sell their buildings which are naturally of poor quality at low prices. More people (43\%) prefer to resettle in location 2 which is undergoing spatial transformation through establishment of local physical plans for residential housing development. Housing standards in location 2 (see Figure 7) are high and this implies similarly higher housing prices than the compensation.
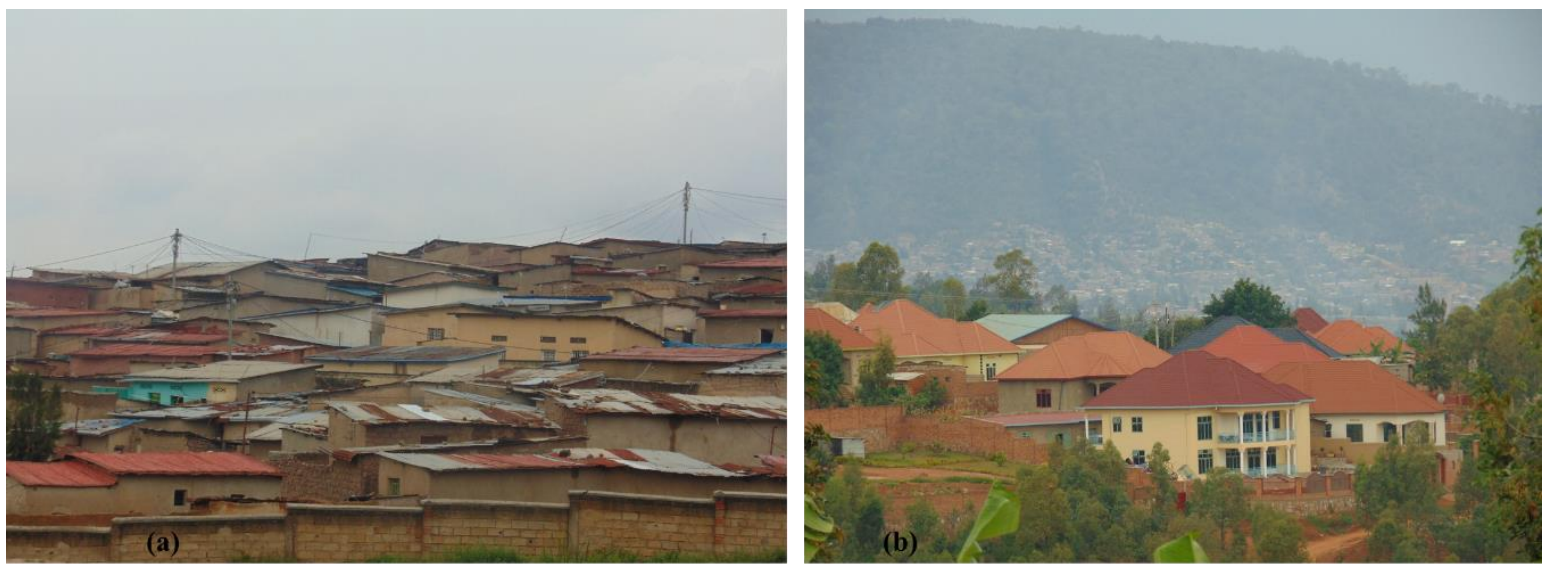

Figure 7. Buildings in the expropriated area and required building in location 2. (a): poor quality aspects of most of buildings which are expropriated; (b): good quality aspects of buildings under development in location 2, according to the current housing development standards. Data source: household survey and field observations. 
The cost of acquiring new buildings in location 3 is also slightly lower than compensation (see Table 5). Location 3 is a remote urban fringe, outside of Kigali city, where housing development standards are affordable for different categories of displaced people ( $48 \%)$. In addition, enforcement of regulations biding housing development is flexible. Therefore this is the favoured destination for low-income groups as they can pay less than the compensation they receive. However, there is high likelihood for the proliferation of informal settlements in location 3, as pointed out in Section 4.1.2.1.

\subsubsection{Decreased Access to Basic Infrastructure and Services}

Migration of expropriated people towards remote areas has an impact on their livelihoods, such as decreased accessibility to basic amenities that they were using before expropriation. This impact has been analysed using distance in meters to basic amenities and services including water, electricity, public transport, education (nursery, primary and secondary), health centres and markets. Figure 8 shows that within core urban areas where expropriated people had been living, access was generally good. This decreases and falls off rapidly outside the core urban, towards the urban fringes, where those people are resettling.

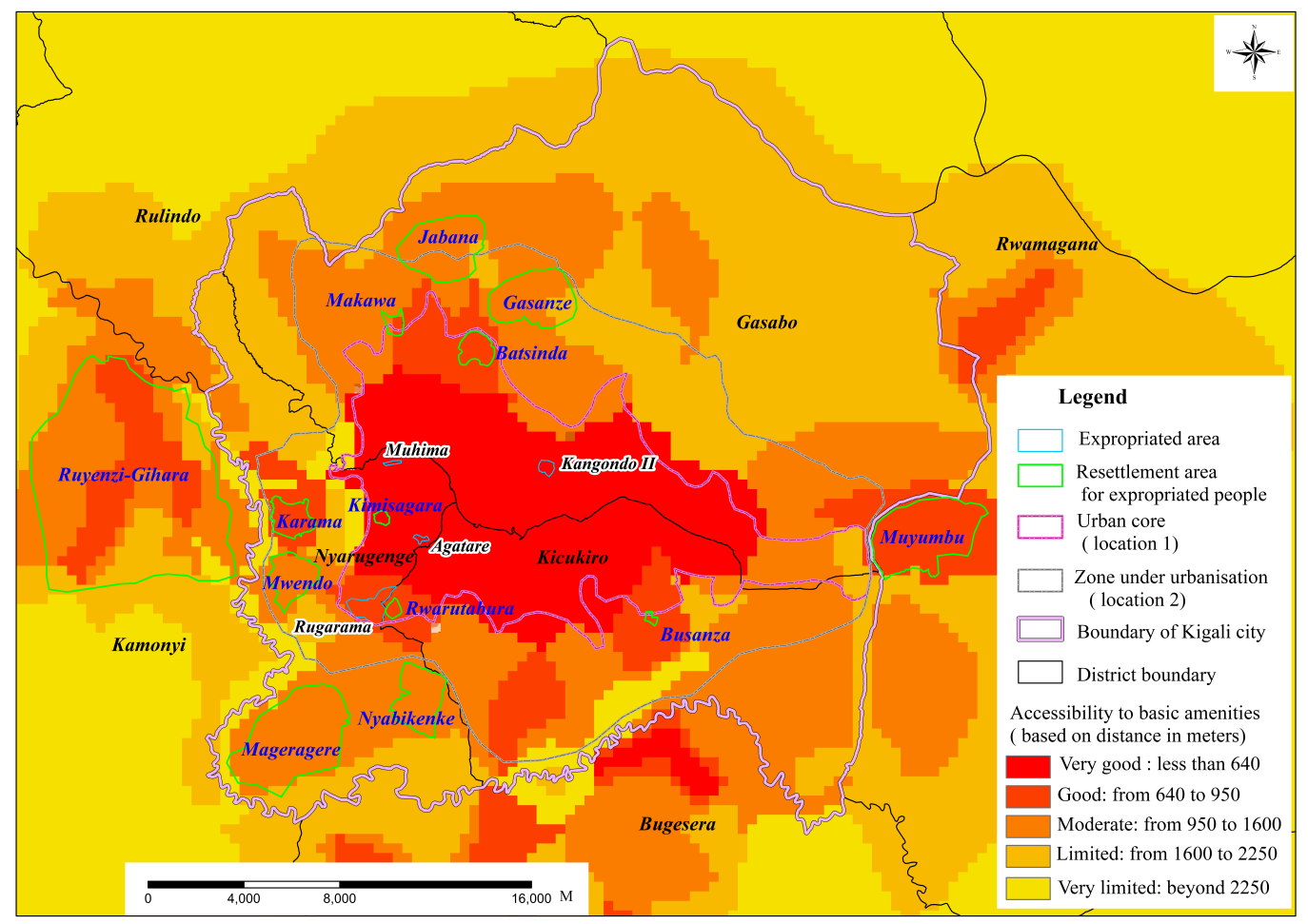

Figure 8. Distance to basic amenities in the origin and destination areas for the expropriated people. Data source: Kigali city, Geo-datasets on socio-economic facilities in Kigali city and neighbouring districts; NSIR and CGIS-UR [40].

As Figure 8 shows, expropriation has been carried out in neighbourhoods where access to basic amenities is generally very good. But, expropriated people cannot afford good properties in neighbourhoods close to where they had been living. As they move further away, they face difficulties in accessing basic amenities, because these areas are not developed to the same degree as Kigali city itself. Compared to situations in previous neighbourhoods, most of these expropriated people travel further to work in the inner city. Increase in the distances they currently travel to the main working places such as the Central Business District (CBD) and the Zone of Main Businesses and Working Opportunities (Z.M.B.W.O) within Kigali city was determined on the basis of the transportation network they use as presented in Figure 9. 


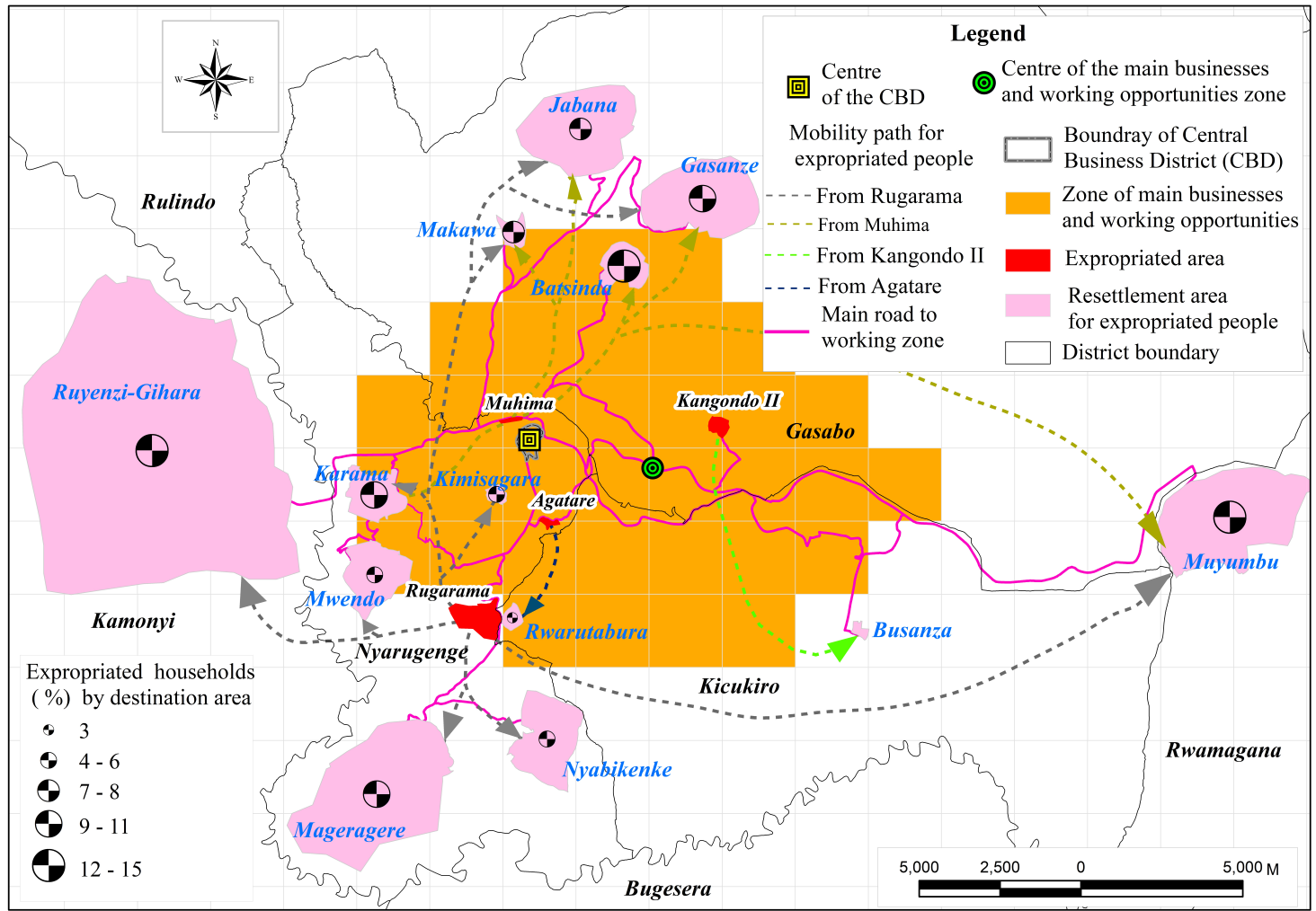

Figure 9. Resettlement sites for expropriated people and travel network to working places. Data source: Kigali city, Geo-datasets on services and business areas in Kigali city; NSIR and CGIS-UR [40]; Household surveys and field observations.

Figure 9 shows that most of the expropriated people resettle in remote areas, far from the areas they had been living. They face the problem of increased travel distance, compared to distances they had been traveling before the expropriation. Changes in those distances were computed and results are presented in Figure 10.

\begin{tabular}{|c|c|c|c|c|c|c|c|}
\hline \multicolumn{4}{|c|}{ Rugarama site } & \multicolumn{4}{|c|}{ Muhima site } \\
\hline \multirow{2}{*}{$\begin{array}{l}\text { Settlement } \\
\text { status }\end{array}$} & \multirow[t]{2}{*}{ Neighbourhood } & \multicolumn{2}{|c|}{ Travel distance ( in $\mathrm{Km}$ ) to } & \multirow{2}{*}{$\begin{array}{l}\text { Settlement } \\
\text { status }\end{array}$} & \multirow[t]{2}{*}{ Neighbourhood } & \multicolumn{2}{|c|}{ Travel distance ( in $\mathrm{Km}$ ) to } \\
\hline & & C.B.D & Z. M B.W.O & & & C.B.D & Z. M B.W.O \\
\hline Previous & Rugarama & 9.1 & 11.4 & Previous & Muhima & 1.2 & 6.4 \\
\hline \multirow{9}{*}{ Current } & Batsinda & 10.3 & 13.8 & \multirow{8}{*}{ Current } & Batsinda & 10.3 & 13.8 \\
\hline & Gasanze & 18.8 & 24.2 & & Gasanze & 18.8 & 24.2 \\
\hline & Jabana & 15.1 & 21.2 & & Jabana & 15.1 & 21.2 \\
\hline & Makawa & 9.1 & 14.5 & & Ruyenzi- & & \\
\hline & $\begin{array}{l}\text { Ruyenzi- } \\
\text { Gihara }\end{array}$ & 15.7 & 21.2 & & Gihara & 15.7 & 21.2 \\
\hline & Mwendo & 13.7 & 19.7 & & Karama & 8.2 & 13.6 \\
\hline & $\rightarrow$ Mageragere & 18.7 & 21.1 & & Mwendo & 13.7 & 19.7 \\
\hline & Nyabikenke & 17.9 & 19.7 & & Muyumbu & 31.8 & 23.9 \\
\hline & Muyumbu & 31.8 & 23.9 & & & & \\
\hline \multicolumn{4}{|c|}{ Agatare site } & \multicolumn{4}{|c|}{ Kangondo II site } \\
\hline \multirow{2}{*}{$\begin{array}{l}\text { Settlement } \\
\text { status }\end{array}$} & \multirow[t]{2}{*}{ Neighbourhood } & \multicolumn{2}{|c|}{ Travel distance ( in $\mathrm{Km}$ ) to } & \multirow{2}{*}{$\begin{array}{l}\text { Settlement } \\
\text { status }\end{array}$} & \multirow[t]{2}{*}{ Neighbourhood } & \multicolumn{2}{|c|}{ Travel distance (in $\mathrm{Km}$ ) to } \\
\hline & & C.B.D & Z.M B.W.O & & & C.B.D & Z.M B.W.O \\
\hline Previous & Agatare & 5.2 & 5.7 & Previous & Kangondo II & 10.4 & 5.2 \\
\hline Current & Rwarutabura & 9.1 & 11.4 & Current & Busanza & 17.9 & 11.8 \\
\hline
\end{tabular}

Figure 10. Travel to working places before and after expropriation. Data source: Kigali city, Geo-datasets on socio-economic facilities in Kigali city and neighbouring districts. Household surveys and field observations. 
In Figure 10, highlighted rows show the situation before the expropriation while others show the current status. The figure can reveal trends of greater travel time and increased transportation cost. Linking this to changes in the access to basic amenities and considering the aspects of compensation value, it is evident that expropriation does not boost the quality of life of the expropriated people. Therefore there is need to improve expropriation processes and amend the current expropriation law in the pursuit of just outcomes. Expropriation options providing the opportunities for those affected to live in similar conditions as before the expropriation would be among aspects to be examined. Areas that require improvement in the three dimensions of spatial justice are highlighted in the conclusion and recommendations that follow.

\section{Conclusion and Recommendations}

This study has unpacked patterns of spatial justice from the current law, processes and outcomes of expropriation in Kigali city. Indicators relating to different aspects of spatial justice were used to decode these patterns. Results show good trends of the three forms of spatial justice in the expropriation law, which relates to the dimension of rules in the applied analytical framework. As parts of findings, very good aspects which are echoed in the law are highlighted below:

- It promotes the compensation (recognitional and redistributive justice) regardless of tenure status.

- It advances sharing the power of eminent domain because private investors can carry out the expropriation if the implementation process of the law opens room for those investors to directly negotiate with property owners on compensation (procedural, recognitional and redistributive justice).

- It grants property owners the rights to use the counter-valuation process, in order to claim for just compensation (procedural, recognitional and redistributive justice).

However, those trends in the three forms of spatial justice are not generally identified at the processes dimension, due to non-compliance with the law by expropriating agencies and valuers. This coalesces to negative outcomes which tend to be unfair and dissatisfactory compensation. Findings have also indicated the ambiguous definition of the public interest and deficiency of the metric of participation in the law and its implementation processes. The law should therefore be revised. Even if just compensation is paid after the counter-valuation, it is not determined using the cost replacement approach which would help the expropriated people acquire new properties in the city. Rethink of the appropriate compensation option which may decrease the displacement effect of the expropriation is suggested. Generally, aspects that should be improved are highlighted below:

\section{* Improvements to the Law}

As a matter of justice in rules dimension, the expropriation law should embrace a participatory conception of justice. It does not provide legal principles on participation and negotiation with property owners whose rights are affected during expropriation. Participation and negotiation feature the aspects of collaboration between actors in expropriation and property owners. It advances transparency in valuation, resulting in appropriate compensation option and value, reflected in the general consensus between expropriating agencies and property owners. The discourse on public interest should also be redefined, due to a critical confusion about public and private interests pushing Kigali city and its constituent districts to undertake expropriation for private investors. The list of activities which are meant to public interest alongside implementation of the master plans should be defined. Thus, this can advance recognition of the rights of property owners to just compensation and all forms of investments that are sought to generate benefits for investors should be called private interests.

\section{* Improvement in the Processes}

The pursuit of just compensation requires the involvement of property owners in all steps of expropriation, including direct negotiation on compensation options and collaboration with valuers in 
compensation calculations. Those features of procedural and recognitional justice provide an open and communicative arena for increasing public trust in agencies undertaking expropriation. It also increases perceptions of fairness of valuation and feelings about just compensation. When expropriation is carried out for public interest, just compensation should be guaranteed using public funds. In all aspects of spatial justice, just compensation can drive from the use of valuation methods which consider market prices and replacement cost. Process of valuation can be more transparent if property valuers hired by the expropriating agencies collaborate with property owners and explain methods and reference prices they use. It can therefore increase acceptance of outcomes of the first valuation, speeding-up the whole expropriation process and decreasing the burden of counter-valuations for some property owners who hardly afford it. Noting that property owners' perception on just compensation is not merely related to the amount of compensation they receive but the fairness and transparency of the whole process of expropriation. Counter-valuation should not be a privileged option for paying appropriate compensation. If expropriating agencies bear the payment of just compensation after counter-valuation, calculating just compensation should be undertaken appropriately at the first valuation as well. Kigali city and its constituent districts establish regular short and mid-term development plans. Expropriation can be planned within those schemes so that an inventory of the properties to be expropriated can be carried out and well estimated cost for compensation included in the budget plans accordingly. When expropriation is carried out for private investment, just compensation should be agreed on between property owners and investors. District authorities or other decision makers should act as mediators and help reach a consensus on compensation options. Independent valuers, selected by both parties should neutrally carry out valuation processes.

\section{* Improvement in the Outcomes}

Even if property valuation can result in paying just compensation, most of expropriated people do not afford other properties in urban area. The consequence is the prevalence of the displacement effect of the expropriation, pushing those people towards remote urban fringes. Shielding them from displacement requires a participatory and communicative approach to just in-kind compensation, especially for expropriation which is meant to develop residential apartments. The in-kind compensation in form of shared-apartments which is being adopted by Rwandan government is a very good decision. It can counteract the proliferation of informal settlements and advance recognition of property owner's rights (recognitional justice). Property owners can collaborate with private investors in valuing their properties and making decisions and plans (procedural justice) on the development of those shared-apartments (redistributive justice). This can therefore result in the co-production of the urban space which advances sustainable and inclusive urban development. Though, findings of this study do not confirm the broad results of other studies conducted on expropriation across the Rwandan territory, they do not diverge. They can therefore serve as guidance on improving the expropriation law and its implementation processes in Kigali city as well as other regions. The study has also alluded on ongoing urban development processes that can be improved through observing spatial justice frames.

Author Contributions: This paper is a part of the ongoing Ph.D. research. Both authors set up the structure of the paper. E.U. contributed to the collection of primary and secondary data, their analysis and all sections of the paper. The Supervisor, W.T.d.V., made a large contribution in supervision of the field survey and the review of the whole manuscript.

Funding: This study is carried out in the general framework of a doctoral research programme at the Technische Universität München (TUM) under the funding of the Deutscher Akademischer Austauschdienst (DAAD), grant number: 57214224. We are very grateful for their financial support. We are also thankful to the German Research Foundation (DFG) and the Technical University of Munich (TUM) which support the publication of this work and the preceding paper (doi:10.3390/land7030084) in the framework of the Open Access Publishing Program.

Acknowledgments: We are grateful to the Mayors of Kigali city and its constituent districts for having granted us the permission to collect primary and secondary data for this study. We highly acknowledge the support of the Director of the Centre for Geographic information Systems and Remote Sensing of the University of Rwanda and 
different people who provided support in collecting those data and all our informants. We are thankful to different staff in the public and private agencies and real property valuers who facilitated access to different documents from which we extracted useful secondary data and the anonymous readers who provided constructive comments on the initial draft of this paper. We are also very grateful to the University of Rwanda which has granted a study leave to Mr. Ernest Uwayezu in order to pursue his Ph.D. programme.

Conflicts of Interest: The authors declare no conflict of interest.

\section{Appendix A}

Table A1. Indicators for evaluating spatial justice trends alongside the expropriation in Kigali city.

\begin{tabular}{|c|c|c|}
\hline & Indicator & Measurement Approach \\
\hline 1 & $\begin{array}{l}\text { Presence of legal provisions defining the public interest as rationale for } \\
\text { government agencies to undertake expropriation }\end{array}$ & Likert scale \\
\hline 2 & Government agencies execute expropriation for the sole public interest & Likert scale \\
\hline 3 & $\begin{array}{l}\text { Percentage of expropriated people whose properties were expropriated } \\
\text { by government agencies for public interest }\end{array}$ & Percentages \\
\hline 4 & $\begin{array}{l}\text { Presence of legal provisions for calculating the compensation value by } \\
\text { an independent valuer }\end{array}$ & Likert scale \\
\hline 5 & Compensation value is calculated by independent valuer & Likert scale \\
\hline 6 & $\begin{array}{l}\text { Percentage of expropriated people whose compensation value was } \\
\text { calculated by independent valuer }\end{array}$ & Percentages \\
\hline 7 & $\begin{array}{l}\text { Presence of legal provisions for negotiating the compensation option } \\
\text { between the expropriating agency and the property owners }\end{array}$ & Likert scale \\
\hline 8 & $\begin{array}{l}\text { Consensus on compensation option is reached between expropriating } \\
\text { agency and property owners prior to valuation }\end{array}$ & Likert scale \\
\hline 9 & $\begin{array}{l}\text { Percentage of expropriated people who negotiated compensation with } \\
\text { expropriating agency }\end{array}$ & Percentages \\
\hline 10 & $\begin{array}{l}\text { Presence of legal provisions for negotiating compensation value } \\
\text { between the expropriating agency and the property owners }\end{array}$ & Likert scale \\
\hline 11 & $\begin{array}{l}\text { Property owners actively participate in valuation process and negotiate } \\
\text { on compensation value }\end{array}$ & Likert scale \\
\hline 12 & $\begin{array}{l}\text { Percentage of expropriated people who actively participated in } \\
\text { valuation process and negotiated compensation value }\end{array}$ & Percentages \\
\hline 13 & Presence of the legal provisions on compensation at market prices & Likert scale \\
\hline 14 & Compensation is calculated at market prices & Likert scale \\
\hline 15 & $\begin{array}{l}\text { Percentage of expropriated people whose compensation has been } \\
\text { calculated at market prices }\end{array}$ & Percentages \\
\hline 16 & $\begin{array}{l}\text { Presence of legal provisions on processes of appealing against } \\
\text { dissatisfactory expropriation process }\end{array}$ & Likert scale \\
\hline 17 & $\begin{array}{l}\text { Presence of accessible appealing system for handling claims on } \\
\text { dissatisfactory compensation value or option }\end{array}$ & Likert scale \\
\hline 18 & $\begin{array}{l}\text { Percentage of the expropriated people who are satisfied with } \\
\text { compensation at first valuation process- }\end{array}$ & Percentages \\
\hline 19 & $\begin{array}{l}\text { Percentage of expropriated people who accessed appealing system and } \\
\text { claimed against dissatisfactory compensation value or option }\end{array}$ & Percentages \\
\hline 20 & $\begin{array}{l}\text { Percentage of expropriated people who are satisfied with the } \\
\text { compensation after appealing/ counter valuation }\end{array}$ & Percentages \\
\hline 21 & $\begin{array}{l}\text { Use of the compensation to access other properties in the close } \\
\text { neighbourhoods }\end{array}$ & Percentages \\
\hline 22 & $\begin{array}{l}\text { Percentage of expropriated people who afford other properties at the } \\
\text { open market, using the compensation fees }\end{array}$ & Percentages \\
\hline
\end{tabular}

Source: Adapted from Uwayezu and de Vries [17]. 


\section{Appendix B}

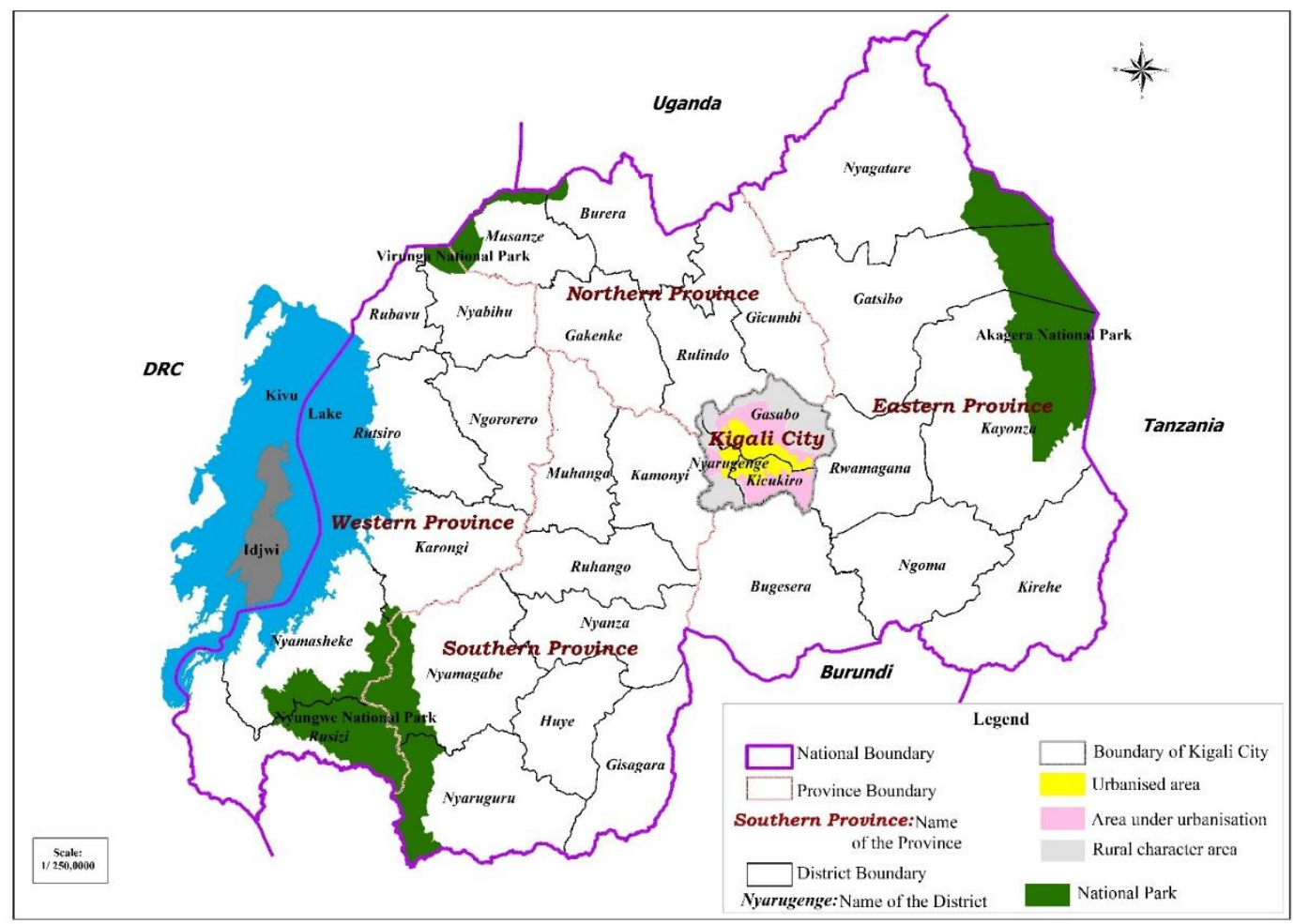

Figure A1. Location of the study area. Data source: NISR and CGIS-UR [40].

\section{Appendix C}

Table A2. Number of the households and sample sizes in the surveyed sites.

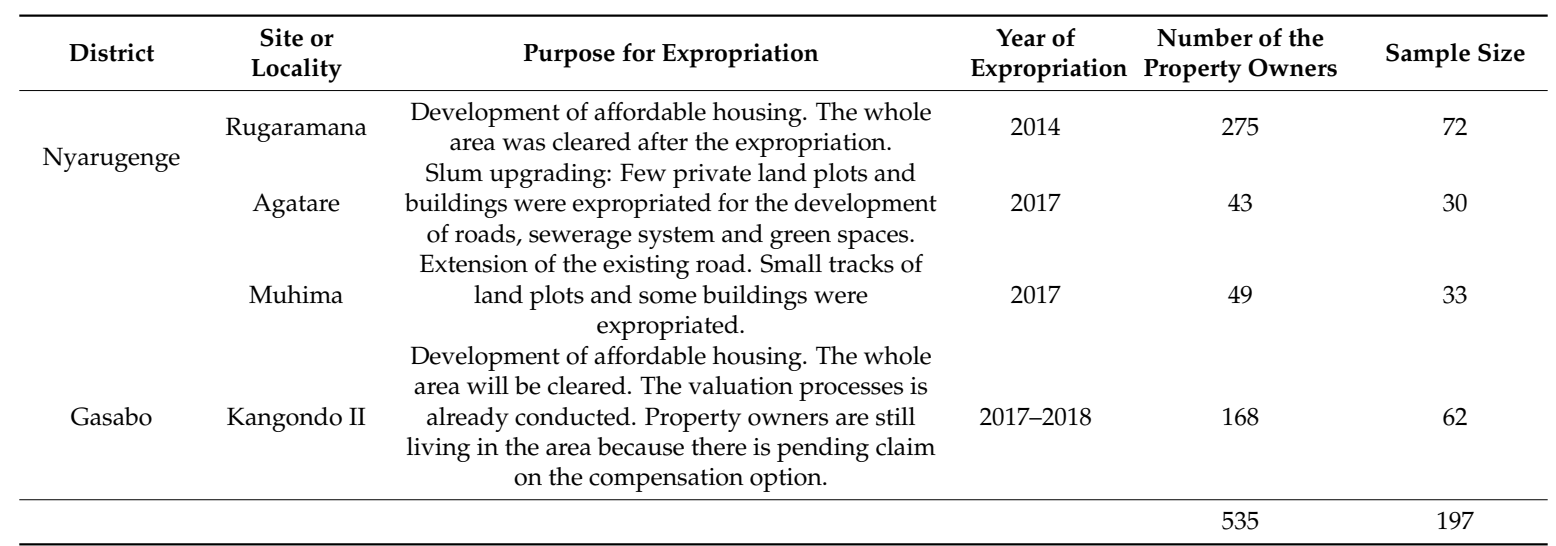




\section{Appendix D}

Table A3. Main characteristics of participants to household survey.

\begin{tabular}{|c|c|c|c|c|}
\hline Characteristic & Class/Category & Number of Respondents & Percentage (\%) & Total Number of Participants \\
\hline \multirow{2}{*}{ Gender } & Male & 144 & 73 & \multirow{2}{*}{197} \\
\hline & Female & 53 & 27 & \\
\hline \multirow{6}{*}{ Age range } & $20-25$ & 5 & 2.5 & \multirow{6}{*}{197} \\
\hline & $25-35$ & 39 & 19.8 & \\
\hline & $35-45$ & 48 & 24.4 & \\
\hline & $45-55$ & 66 & 33.5 & \\
\hline & $55-65$ & 31 & 15.7 & \\
\hline & Over 65 & 8 & 4.1 & \\
\hline \multirow{3}{*}{ Marital status } & Single & 6 & 3.0 & \multirow{3}{*}{197} \\
\hline & Married & 167 & 84.8 & \\
\hline & Widow & 24 & 12.2 & \\
\hline \multirow{4}{*}{ Education level } & None & 6 & 3.0 & \multirow{4}{*}{197} \\
\hline & Primary & 71 & 36.0 & \\
\hline & Secondary & 79 & 40.1 & \\
\hline & Tertiary & 41 & 20.8 & \\
\hline \multirow{11}{*}{$\begin{array}{l}\text { Income level } \\
\text { (per month, in } \\
\text { USD) }\end{array}$} & $70-150$ & 31 & 15.7 & \multirow{11}{*}{197} \\
\hline & $150-220$ & 2 & 1.0 & \\
\hline & $220-300$ & 59 & 29.9 & \\
\hline & $300-365$ & 52 & 26.4 & \\
\hline & $365-440$ & 5 & 2.5 & \\
\hline & $440-510$ & 15 & 7.6 & \\
\hline & 510-585 & 19 & 9.6 & \\
\hline & $585-660$ & 6 & 3.0 & \\
\hline & 660-730 & 3 & 1.5 & \\
\hline & $730-805$ & 4 & 2.0 & \\
\hline & 880-950 & 1 & 0.5 & \\
\hline
\end{tabular}

\section{Appendix E}

Table A4. Variation in land prices from 2015 to 2018.

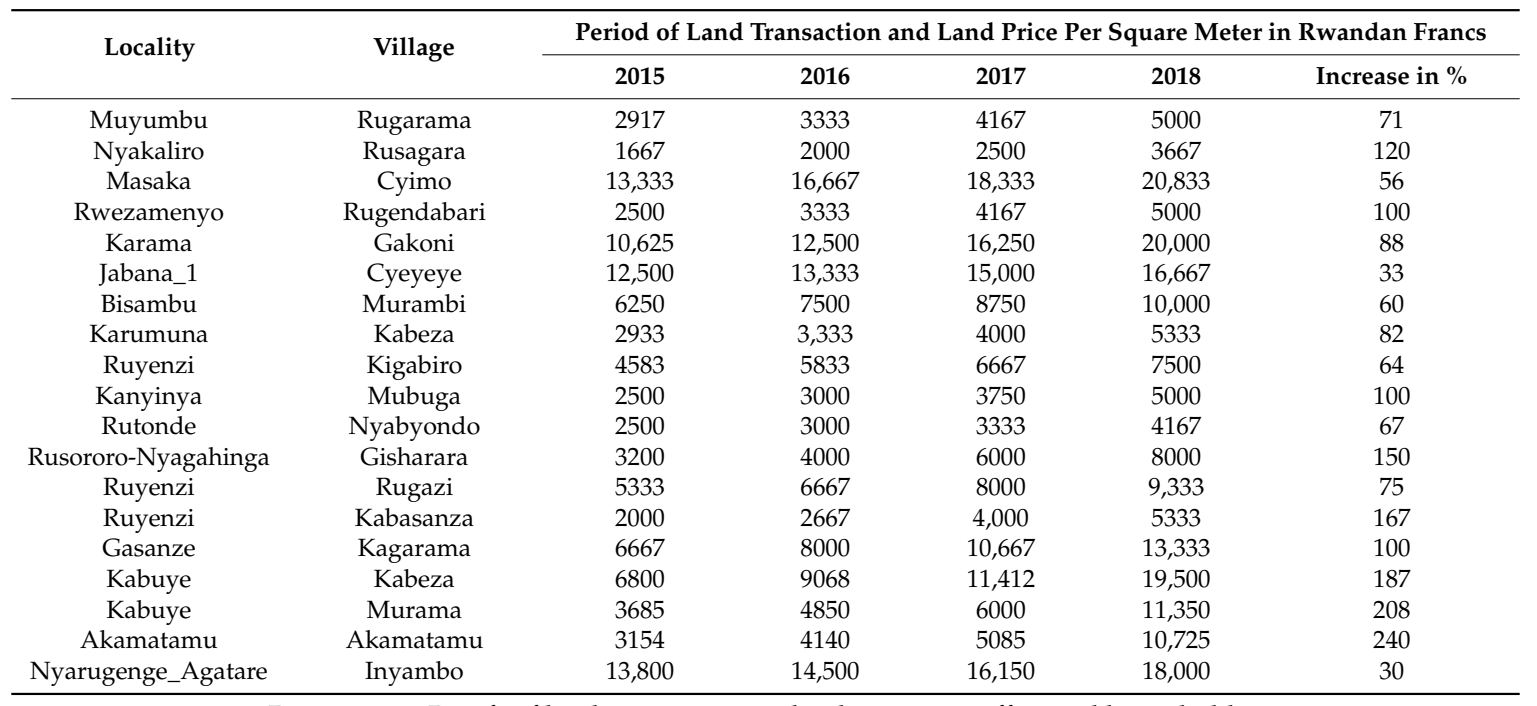

Data source: Proofs of land transactions at land managers office and households. 


\section{Appendix F}

Table A5. Property owners' decisions/perceptions on appealing and using counter-valuation processes.

\begin{tabular}{|c|c|c|c|c|c|}
\hline Age & Sex & Level of Education & Marital Status & Year of Expropriation & Opinions on or Drivers for Appealing \\
\hline 55 & $\mathrm{~F}$ & Primary & Married & 2017 & $\begin{array}{l}\text { "I have fear for appealing, though I am not satisfied with the compensation. } \\
\text { Local community does not have to challenge the government." }\end{array}$ \\
\hline 57 & M & Secondary & Married & 2017 & $\begin{array}{l}\text { "That (compulsory real property acquisition) started some years ago, when they } \\
\text { introduced the lease property regime. As the land belongs to the government, it is not } \\
\text { worth claiming. They can even take the land without compensation." }\end{array}$ \\
\hline 49 & $\mathrm{~F}$ & Primary & Widow & 2014 & $\begin{array}{l}\text { "I was not satisfied with the compensation. I did not appeal because other people who } \\
\text { appealed did not receive positive feedback from the expropriating agency." } \\
\text { "I follow the land market information. I appealed. It is my right. Through }\end{array}$ \\
\hline 47 & M & University & Married & 2014 & $\begin{array}{c}\text { counter-valuation I received a higher compensation value than the one that was } \\
\text { determined during the first valuation." }\end{array}$ \\
\hline 53 & $\mathrm{M}$ & None & Married & 2014 & $\begin{array}{c}\text { "None can resist against the government decision. All people that I know and who } \\
\text { claimed did not get a positive feedback." }\end{array}$ \\
\hline 67 & M & None & Married & 2017 & $\begin{array}{c}\text { "We accept to receive low compensation without complaining because we do not want to } \\
\text { challenge the government process. I cannot spend a little money that I have on appealing. } \\
\text { How can I be sure that the counter valuation will be in my favour?" }\end{array}$ \\
\hline 39 & M & University & Married & 2017 & $\begin{array}{c}\text { "The calculated value for the compensation was too low. If I had to sell my house at the } \\
\text { open market, I could receive much money. I appealed. After the counter-valuation, the } \\
\text { compensation value was increased at } 45 \% . "\end{array}$ \\
\hline 62 & $\mathrm{~F}$ & Primary & Widow & 2017 & $\begin{array}{c}\text { "The compensation value was too low, compared to the price at which I can sell my house } \\
\text { at the open market. But, I did not appeal. I could not find 60, } 000 \text { Rfws for the payment of } \\
\text { the counter-valuation process." }\end{array}$ \\
\hline
\end{tabular}

Data source: Interviews and focus group discussion with expropriated people from Agatare and Rugarama, February-March, 2018. 


\section{References}

1. Ministry of Finance and Economic Planning and National Institute of Statistics of Rwanda. Fourth Population and Housing Census, Rwanda, 2012; Ministry of Finance and Economic Planning and National Institute of Statistics of Rwanda: Kigali, Rwanda, 2014. Available online: www.statistics.gov.rw/survey-period/fourthpopulation-and-housing-census-2012 (accessed on 7 June 2018).

2. Manirakiza, V. Urbanization Issue in the Era of Globalization: Perspectives for Urban Planning in Kigali. In Social Studies for Community Cohesion and Sustainable Development; International Household Survey Network: Kigali, Rwanda, 2012; Available online: https: / / docplayer.net/21199533-Urbanization-issue-in-the-era-ofglobalization-perspectives-for-urban-planning-in-kigali-vincent-manirakiza.html (accessed on 7 June 2017).

3. World Bank Group. Reshaping Urbanization in Rwanda: Urbanization and the Evolution of Rwanda's Urban Landscape; World Bank Group: Washington, DC, USA, 2017; 40p. Available online: https:/ /openknowledge. worldbank.org/handle/10986/29081 (accessed on 7 June 2018).

4. Rwanda Environment Management Authority. Kigali: State of Environment and Outlook Report 2013; Rwanda Environment Management Authority: Kigali, Rwanda, 2013; 40p. Available online: http:/ /www.minirena. gov.rw / fileadmin/Media_Center/Documents/kigali_soe_part1-1.pdf (accessed on 7 June 2018).

5. Ministry of Infrastructure. National Urbanization Policy; Ministry of Infrastructure: Kigali, Rwanda, 2015; 52p. Available online: www.mininfra.gov.rw/fileadmin/Rwanda_National_Urbanization_Policy_2015.pdf (accessed on 7 June 2018).

6. Ministry of Infrastructure. National Housing Policy; Government of Rwanda: Kigali, Rwanda, 2015; 63p. Available online: www.rha.gov.rw/fileadmin/user_upload/Documents/.../National_Housing_Policy.pdf (accessed on 7 June 2018).

7. City of Kigali. The City of Kigali Development Plan (2013-2018); City of Kigali: Kigali, Rwanda, 2013; 98p. Available online: http:/ / www.kigalicity.gov.rw/fileadmin/Template/Documents/policies/Kigali_City_ Development_Plan_2013-2018_City_development_Plan_pdf (accessed on 8 June 2018).

8. Goodfellow, T.; Smith, A. From Urban Catastrophe to 'Model' City? Politics, Security and Development in Post-conflict Kigali. Urban Stud. 2013, 50, 3185-3202. [CrossRef]

9. Manirakiza, V.; Ansoms, A. Modernizing Kigali: The struggle for space in the Rwandan urban context. In Losing Your Land Dispossession in the Great Lakes; Ansoms, A., Hilhorst, T., Eds.; Boydell and Brewer: Woodbridge, NJ, USA, 2014; 218p.

10. Goodfellow, T. Rwanda's political settlement and the urban transition: Expropriation, construction and taxation in Kigali. J. East. Afr. Stud. 2014, 8, 311-329. [CrossRef]

11. Government of Rwanda. Law $N^{\circ} 32 / 2015$ of 11/06/2015 Relating to Expropriation in the Public Interest; Government of Rwanda: Kigali, Rwanda, 2015; 54p. Available online: https://landportal.org/library/ resources / rwanda-land-lawspolicies-2/law-n\%C2\%B0-322015-11062015-relating-expropriation-public (accessed on 8 June 2018).

12. Tagliarino, N.K.; Bununu, Y.A.; Micheal, M.O.; de Maria, M.; Olusanmi, A. Compensation for Expropriated Community Farmland in Nigeria: An In-Depth Analysis of the Laws and Practices Related to Land Expropriation for the Lekki Free Trade Zone in Lagos. Land 2018, 7, 23. [CrossRef]

13. Hoops, B.; Marais, E.J.; Mostert, H.; Sluysman en, J.A.M.A.; Verstappen, L.C.A. Rethinking Expropriation Law I: Public Interest in Expropriation; Eleven International Publishing: Hague, The Netherlands, 2015; Volume 6, $410 \mathrm{p}$.

14. Rose, H.; Mugisha, F.; Kananga, A.; Clay, D. The implementation of Rwanda's expropriation law and its Outcomes on the population. In Proceedings of the 2016 World Bank Conference on Land and Poverty, Washington, DC, USA, 14-18 March 2016; The World Bank: Washington, DC, USA, 2016. Available online: https://www.land-links.org/research-publication/the-implementation-of-rwandasexpropriation-law-and-its-outcomes-on-the-population/ (accessed on 19 July 2018).

15. Legal Aid Forum. The Implementation of Rwanda's Expropriation Law and Outcomes on the Population: Final Report; USAID: Kigali, Rwanda, 2015; 231p. Available online: https:/ /landportal.org/fr/library/resources/ rwanda-land-research-104/final-report-rwanda\%E2\%80\%99s-expropriation-law-and-outcomes (accessed on 22 August 2018).

16. He, J.; Sikor, T. Notions of justice in payments for ecosystem services: Insights from China's Sloping Land Conversion Program in Yunnan Province. Land Use Policy 2015, 43, 207-216. [CrossRef] 
17. Uwayezu, E.; de Vries, T.W. Indicators for Measuring Spatial Justice and Land Tenure Security for Poor and Low Income Urban Dwellers. Land 2018, 7, 84. [CrossRef]

18. Food and Agriculture Organization of the United Nations. Voluntary Guidelines on the Responsible Governance of Tenure of Land, Fisheries and Forests in the context of National Food Security; FAO: Rome, Italy, 2012; Available online: http:/ /www.fao.org/tenure/voluntary-guidelines/en/ (accessed on 27 September 2018).

19. Hoops, B.; Marais, E.J.; van Schalkwyk, L.; Tagliarino, N.K. (Eds.) Rethinking Expropriation Law III. Fair Compensation; Eleven International Publishing: Hague, The Netherlands, 2018; Volume 9, 244p.

20. World Bank. Environmental and Social Standard 5 Land Acquisition, Restrictions on Land Use and Involuntary Resettlement; World Bank: Washington, DC, USA, 2015; 13p. Available online: https: / / consultations.worldbank.org/Data/hub/files/consultation-template/review-and-updateworld-bank-safeguard-policies/en/materials / proposed_environmental_and_social_standards_-_ess5_ factsheet_and_standard.pdf (accessed on 3 October 2018).

21. Nozick, R. Anarchy, State, and Utopia; Basic Books: New York, NY, USA, 1974; 367p, ISBN 9780465097203.

22. Rawls, J. A Theory of Justice; Revised Edition; Cambridge University Press: Cambridge, MA, USA, 1999; 560p, ISBN 9780674000780.

23. Fainstein, S.S. Spatial justice and planning. Justice Spatiale|Spatial Justice 2009. Available online: http:/ / www.jssj.org (accessed on 12 August 2018).

24. Gutwald, R.; Leßmann, O.; Masson, T.; Rauschmayer, F. A Capability Approach to Intergenerational Justice? Examining the Potential of Amartya Sen's Ethics with Regard to Intergenerational Issues. J. Hum. Dev. Capab. 2014, 15, 355-368. [CrossRef]

25. Soja, E. The City and Spatial Justice. Justice Spatiale ISpatial Justice 2009. pp. 31-39. Available online: https:/ /www.jssj.org/wp-content/uploads/2012/12/JSSJ1-5en1.pdf. (accessed on 12 August 2018).

26. Ferrari, E. Competing Ideas of Social Justice and Space: Locating Critiques of Housing Renewal in Theory and in Practice. Int. J. Hous. Policy 2012, 12, 263-280. [CrossRef]

27. Watkins, C. Representations of Space, Spatial Practices and Spaces of Representation: An Application of Lefebvre's Spatial Triad. Cult. Organ. 2005, 11, 209-220. [CrossRef]

28. Fraser, N. Recognition without Ethics? Theory Cult. Soc. 2001, 18, 21-42. [CrossRef]

29. Young, I.M. Justice and the Politics of Difference; Princeton University Press: Princeton, NJ, USA, 1990; 286p, ISBN 9780691023151.

30. Fraser, N.; Honneth, A. Redistribution or Recognition? A Political-philosophical Exchange; Verso Books: London, UK; New York, NY, USA, 2003; 276p, ISBN 1859844928.

31. Lawrence, R.L.; Daniels, S.E.; Stankey, G.H. Procedural justice and public involvement in natural resource decision making. Soc. Nat. Resour. 1997, 10, 577-589. [CrossRef]

32. Stern, S. Remodeling Just Compensation: Applying Restorative Justice to Takings Law Doctrine. Can. J. Law Jurisprud. 2017, 30, 413-441. [CrossRef]

33. Burke, K.; Leben, S. Procedural Fairness: A Key Ingredient in Public Satisfaction. Court Rev. J. Am. Judges Assoc. 2007, 44, 226.

34. Lefebvre, H. The Production of Space; Basil Blackwell: Oxford, UK, 1991; 464p.

35. Deininger, K.; Augustinus, C.; Enemark, S.; Munro-Faure, P. Innovations in Land Rights Recognition, Administration, and Governance; World Bank Studies; World Bank: Washington, DC, USA, 2010.

36. Knetsch, J.L.; Borcherding, T.E. Expropriation of Private Property and the Basis for Compensation. Univ. Tor. Law J. 1979, 29, 237-252. [CrossRef]

37. Fraser, N. From Redistribution to Recognition? Dilemmas of Justice in a 'Post-Socialist' Age. New Left Rev. I 1995, 212, 68-93.

38. de Vries, W.T.; Uchendu, E.C. Responsible land management-Concept and application in a territorial rural context fub. Flächenmanagement und Bodenordnung 2017, 2, 65-73.

39. Deininger, K.; Selod, H.; Burns, A. The Land Governance Assessment Framework: Identifying and Monitoring Good Practice in the Land Sector; The World Bank: Washington, DC, USA, 2012; 380p.

40. National Institute of Statistics of Rwanda (NISR) and Centre for Geographic information Systems and Remote Sensing of the University of Rwanda(CGIS-UR). Administrative Map of Rwanda; CGIS-UR: Kigali, Rwanda, 2012.

41. Krishnaswamy, K.N.; Sivakumar, A.I.; Mathirajan, M. Management Research Methodology: Integration of Principles, Methods and Techniques; Pearson Education: Bengaluru, India, 2006; 600p, ISBN 8131767779. 
42. Torrance, H. Triangulation, Respondent Validation, and Democratic Participation in Mixed Methods Research. J. Mix. Methods Res. 2012, 6, 111-123. [CrossRef]

43. Institute of Real Property Valuers in Rwanda. Rwanda Lands and Property Incorporated Thereon Reference Prices; Institute of Real Property: Kigali, Rwanda, 2018; 346p. Available online: https:/ / rwandalii.africanlii.org/ content/official-gazette-n\%C2\%BA-special-8112018 (accessed on 20 November 2018).

44. Börzel, T.A.; Hofmann, T.; Panke, D. Caving in or sitting it out? Longitudinal patterns of non-compliance in the European Union. J. Eur. Public Policy 2012, 19, 454-471. [CrossRef]

45. Rwanda Governance Board. Citizen Report Card-CRC 2017; Rwanda Governance Board: Kigali, Rwanda, 2017; 156p. Available online: http:/ /rgb.rw/publications/citizen-report-card/ (accessed on 11 October 2018).

46. Never Again Rwanda. Local Government Imihigo Process: Understanding the Factors Contributing to Low Citizen Participation; Never Again Rwanda: Kigali, Rwanda, 2018; 70p. Available online: http:/ / neveragainrwanda. org / file/1389/download?token=mJ-gjTkT (accessed on 11 October 2018).

47. Government of Rwanda. Law N 17/2010 of 12/05/2010 Establishing and Organizing the Real Property Valuation Profession in Rwanda; Government of Rwanda: Kigali, Rwanda, 2010; 120p.

48. Government of Rwanda. Ministerial Order $N^{\circ}$ 001/16.00 of 23/11/2009 Determining the Reference Land Prices in the City of Kigali; Government of Rwanda: Kigali, Rwanda, 2009; 12p. Available online: http:/ / www.minicom.gov.rw/fileadmin/minicom_publications/law_and_regurations/Law_relating_to_ electronic_messages_electronic_signatures_and_electronic_transactions.pdf (accessed on 27 July 2018).

49. Cao, Y.; Zhang, X. Are they satisfied with land taking? Aspects on procedural fairness, monetary compensation and behavioral simulation in China's land expropriation story. Land Use Policy 2018, 74, 166-178. [CrossRef]

50. Norwegian People's Aid and Rwanda Civil Society Platform. Analysis of Land Expropriation and Transfer Process in Rwanda; Norwegian People's Aid and Rwanda Civil Society Platform: Kigali, Rwanda, 2017; 85p. Available online: http:/ / www.rcsprwanda.org/IMG/pdf/report_on_land.pdf (accessed on 20 July 2018).

51. Harvey, D. Social Justice and the City; Geographies of Justice and Social Transformation Series; University of Georgia Press: Athens, GA, USA, 2010; Volume 1, 356p, ISBN 9780820336046.

(C) 2019 by the authors. Licensee MDPI, Basel, Switzerland. This article is an open access article distributed under the terms and conditions of the Creative Commons Attribution (CC BY) license (http:/ / creativecommons.org/licenses/by/4.0/). 